\title{
Этапы формирования Южно-Алтайского метаморфического пояса (Центральная Азия)
}

Козаков И. К., Сальникова Е. Б., Иванова А. А., Плоткина Ю. В.

\begin{abstract}
Аннотация
И.К. Козаков, Е.Б. Сальникова, А.А. Иванова, Ю.В. Плоткина

Герцинские подвижные пояса в Центральной Азии включают собственно герцинский и позднегерцинский (индосинийский) пояса, становление которых связано с развитием Южно- и Внутренне-Монгольских палеоокеанических бассейнов. Кристаллические комплексы в пределах Южно-Алтайского метаморфического пояса (ЮАМП) слагают тектонические пластины разного масштаба, в которых уровень метаморфизма на ранних этапах достигал условий высокотемпературных субфаций амфиболитовой и, местами, гранулитовой фаций. В тектоническом плане полоса их выходов приурочена к окраине Северо-Азиатского каледонского континента и протягивается с юго-востока на северо-запад вдоль южного склона Гобийского, Монгольского и Китайского Алтая в Восточный Казахстан, где они представлены в Иртышской сдвиговой зоне. Эти образования объединяются нами в составе герцинского Южно-Алтайского метаморфического пояса ЮАМП протяженностью более 1500 км. В его составе представлены поли- и монометаморфические комплексы. Ранний эпизод метаморфизма происходил в условиях пониженного давления, поздний - повышенного в интервалах 390-385 и 375-360 млн лет, соответственно. Эти процессы происходили в ходе закрытия бассейна с океанической корой тетического ряда Южно-Монгольского океана (Палеотетис I). Пространственное положение ЮАМП обусловлено асимметричностью строения бассейна, в котором активная континентальная окраина представлена вдоль его северной части, пассивная - вдоль южной (в современных координатах).
\end{abstract}

Ключевые слова: полиметаморфизм, геохронология, геодинамические обстановки.

\section{Ключевые слова:}

Полиметаморфизм, геохронология, геодинамические обстановки., Центрально-Азиатский складчатый пояс 


\title{
ЭТАПЫ ФОРМИРОВАНИЯ ЮЖНО-АЛТАЙСКОГО МЕТАМОРФИЧЕСКОГО ПОЯСА (ЦЕНТРАЛЬНАЯ АЗИЯ)
}

\author{
И.К. Козаков, Е.Б. Сальникова, А.А. Иванова, Ю.В. Плоткина \\ ${ }^{1}$ Институт геологии и геохронологии докембрия РАН, Санкт-Петербург
}

Герцинские подвижные пояса в Центральной Азии включают собственно герцинский и позднегерцинский (индосинийский) пояса, становление которых связано с развитием Южно- и Внутренне-Монгольских бассейнов с океанической корой. Кристаллические комплексы в пределах Южно-Алтайского метаморфического пояса (ЮАМП) слагают тектонические пластины разного масштаба, в которых уровень метаморфизма на ранних этапах достигал условий высокотемпературных субфаций амфиболитовой и, местами, гранулитовой фаций. В тектоническом плане полоса их выходов приурочена к окраине Северо-Азиатского каледонского континента и протягивается с юго-востока на северо-запад вдоль южного склона Гобийского, Монгольского и Китайского Алтая в Восточный Казахстан, где они представлены в Иртышской сдвиговой зоне. Эти образования объединяются нами в составе герцинского Южно-Алтайского метаморфического пояса ЮАМП протяженностью более 1500 км. В его составе представлены поли- и монометаморфические комплексы. Для Цэлской тектонической пластины Гобийского Алтая юго-посточной части ЮАМП определен возраст гранитоидов, определяющих возрастной интервал позднего эпизода метаморфизма: $374 \pm 2$ 360 \pm 5 млн лет. Эти и ранее полученные результаты показывают, что ранний эпизод метаморфизма пониженного давления, и поздний - повышенного, происходили в интервалах 390-385 и 375-360 млн лет практически на всем протяжении Данного пояса. В промежутке между ними фиксируется кратковременная стадия стабилизации. Эти процессы происходили в ходе закрытия бассейна с океанической корой тетического ряда Южно-Монгольского океана (Палеотетис I). Пространственное положение ЮАМП обусловлено асимметричностью строения бассейна, в котором активная континентальная окраина представлена вдоль его северной части, пассивная вдоль южной (в современных координатах).

Ключевые слова: Центрально-Азиатский складчатый пояс, герциниды, полиметаморфизм, рои даек, геодинамические обстановки.

\section{Введение}

Складчатые сооружения Центральной Азии характеризуются двумя основными типами тектонических структур - мозаичными и линейными (Мосаковский и др., 1993, 
Диденко и др., 1994). К первому типу относятся, главным образом, байкальские и каледонские структуры, ко второму - герцинские подвижные пояса западной части АлтаеСаянской области и Южной Монголии (рис. 1). Вдоль их границы с каледонидами выделяется Гоби-Алтайская зона, которая рассматривается как краевая часть каледонского палеоконтинента (Руженцев и др., 1991; Руженцев, Поспелов, 1992).

В тектоническом плане формирование Южно-Алтайского метаморфического пояса обусловлено его положением вдоль зоны сочленения каледонид и герцинид (рис. 1). В статье обсуждаются результаты структурно-геологических и геохронологических исследований, позволяющие представить схему формирования герцинских моно- и полиметаморфических комплексов. Установленные особенности становления и развития этих поясов дают возможность определить геодинамические обстановки проявления процессов регионального метаморфизма в линейных аккреционно-коллизионных структурах центрального сегмента Центрально-Азиатского складчатого пояса.

\section{Геологическое положение метаморфических комплексов.}

В Гоби-Алтайской зоне вдоль южного склона Гобийского, Монгольского и Китайского Алтая, а также в Восточном Казахстане (в Иртышской сдвиговой зоне) в тектонических пластинах разного масштаба представлены кристаллические породы, которые объединены нами в Южно-Алтайский метаморфический пояс - ЮАМП. Они слагают тектонические пластины шириной от сотен метров до 15-20 км и протяженностью от первых до 50-60 км. С севера они ограничены системой вязких разрывов, параллельных северо-западным структурам зеленосланцевых толщ палеозоя, а с юга срезаны северозападными и субширотными зонами милонитов, связанными с глубинными разломами (Иртышским, Булганским, Заалтайским), которыми отделены от островодужных и океанических комплексов герцинид (рис 1). На всём протяжении ЮАМП в тектонических пластинах представлены: биотитовые и гранат-биотовые гнейсы, содержащие ставролит и кианит, андалузит, силлиманит, а также биотит-роговообманковые гнейсы, амфиболовые кристаллические сланцы, амфиболиты, сформировавшиеся при метаморфизме осадочных и вулканогенных пород. Среди них развиты тела и массивы гранитоидов (син- и постметаморфических) и дайки метабазитов. Во многих пластинах было устанавлено проявление процессов полиметаморфизма, который изначально был определен только структурно-геологическими методами, и относились к докембрию (Козаков, 1986). Позднее они были охарактеризованы результатами геохронологических исследований цирконов U-Pb методом, которые дали основания для корреляции с развитием герцинид (ID TIMS, Бибикова, и др. 1992) ${ }^{1}$ и были исследованы петрологическими методами 
(Козаков и др., 2002, 2011; Полянский и др., 2011; Сухоруков, 2007; Сухоруков и др., 2016). В пределах пояса пластины метаморфических пород разделены зонами расссланцевания, ориентированными, как правило, согласно с главной картируемой северо-западной (реже субширотной) структурой пояса.

РТ условия метаморфизма. В тектонических пластинах ЮАМП фиксируется проявление зонального регионального метаморфизма кианит-силлиманитовой фациальной серии $\mathrm{M}_{2}$. Для ставролитовых и кианитовых парагенезисов, развитых в Монгольском Алтае получены значения температур и давлений в диапазоне 560 - $630{ }^{\circ} \mathrm{C}$ и 5.5 - 7.5 кбар (Козаков и др., 2002, 2011). Данные парагенезисы также широко развиты в тектонических пластинах Китайского Алтая и Иртышской сдвиговой зоны Восточного Казахстана (рис. 1), где для гранат-кианит-биотитовых гнейсов Предгорненской пластины получены близкие значения $P-T$ условий метаморфизма: $580-600^{\circ} \mathrm{C}$ и $5.8-6.2$ кбар (Козаков и др., 2011).

К более ранним относятся реликтовые парагенезисы метаморфизма андалузитсиллиманитовой фациальной серии, сопровождавшегося интенсивной мигматизацией и достигавшего уровня гранулитовой фации $\mathrm{M}_{1}$. Породы с парагенезисами раннего метаморфизма устанавливаются только в виде реликтов в будинах или тектонических линзах. В гранулитах Цогтской пластины Гобийского Алтая (рис. 2) для парагенезиса плагиоклаз + ортопироксен + клинопироксен + биотит + квари определены РТ условия $870{ }^{\circ} \mathrm{C}$ и 5.7 кбар (Козаков, и др., 2002). В Бодончинской пластине в более низкотемпературных зонах условия метаморфизма $\mathrm{M}_{1}$ определены в интервале $520-560{ }^{\circ} \mathrm{C}$ и 3-3.6 кбар; для наиболее широко развитых на Монгольском Алтае ставролитовых и кианитовых парагенезисов позднего эпизода метаморфизма $\left(\mathrm{M}_{2}\right)$ получены значения в диапазоне 560-630 ํㅡ и 5.5-7.5 кбар (Козаков и др., 2011). В Булганской тектонической пластине реликты гиперстена установлены среди диопсидовых гнейсов, слагающих центральные части будин, среди гнейсов с парагенезисом метаморфизма повышенного давления: кианит - гранат - ставролит - мусковит - биотит - плагиоклаз - кварц (Козаков, 1986). Это позволило связывать формирование данного метаморфизма с наложением на ранее высокометаморфизованные породы.

Структуру большинства тектонических пластин пояса определяет поздний эпизод метаморфизма повышенных давлений $\left(\mathrm{M}_{2}\right)$ и сопряженные с ним деформации внутреннюю. При этом повторное наложение метаморфизма во многих случаях «стирает» парагенезисы раннего метаморфизма $\left(\mathrm{M}_{1}\right)$.

получен методом - $\mathrm{Pb}-\mathrm{Pb}$ evaporation. В исследованиях авторов данный метод не использовался и применялся U-Pb метод по циркону (ID TIMS); использование других методов указывается в тексте. 
Геохронология. В Цогтской тектонической пластине ЮАМП возраст раннего эпизода метаморфизма $\mathrm{M}_{1}$ фиксируют синметаморфические амфиболовые монцодиориты - $385 \pm 2$ млн лет, прорывающие мигматизированные роговообманковые гнейсы с реликтами гиперстеновых гнейсов, и в свою очередь прорванные дайками гашуннурского комплекса, а затем совместно переработанные в условиях амфиболитовой фации в ходе метаморфизма $\mathrm{M}_{2}$ (ID-TIMS, Бибикова и др., 1992). Возраст более позднего эпизода метаморфизма повышенного давления $\mathrm{M}_{2}$ определяют цирконы из синметаморфических расслоенного габбро и трондьемитов массива Эхний-ус Бодончинской тектонической пластины - $371 \pm 2$ и $365 \pm 4$ млн лет, соответственно (ID-TIMS, Бибикова и др., 1992). В габбро-диоритах массива присутствуют также ксенолиты смятых в складки мигматизированных гнейсов, связанных с более ранним эпизодом метаморфизма. Сходные оценки возраста раннего и позднего эпизодов метаморфизма (384 \pm 2 и $358 \pm 6$ млн лет) были получены для метаморфогенных цирконов из мигматизированных гнейсов, содержащих реликты гиперстена Цогтской пластины в долине реки Гэгэтин-Гол (ID-TIMS, Бибикова и др., 1992; Козаков и др., 2002).

Оценка нижней границы накопления метатерригенных пород Бодончинской тектонической пластины была определена возрастом детритовых цирконов - $458 \pm 4.5$

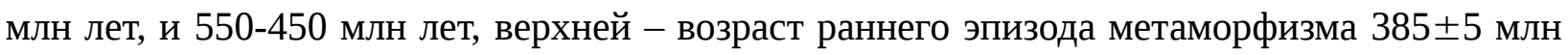
лет (ID TIMS, Козаков и др. 2009; LA ICP-MS, Jiang et al., 2012). То есть возрастной интервал их накопления не превышал 60-70 млн лет, что соответствует позднему ордовику - раннему девону.

В тектонических пластинах ЮАМП Китайского Алтая (рис. 2) присутствуют гнейсы со ставролитом, кианитом и гранатом, но также и с андалузитом, кордиеритом и силлиманитом (Windley et al., 2002, Zheng et al., 2007). В них для гранитоидов, завершающих поздний эпизод метаморфизма, установлен возраст $373 \pm 2$ млн лет (IDTIMS, Козаков и др., 2011) (рис. 3). В северо-западной части Китайского Алтая представлены гранитоиды с возрастом 462 \pm 10 млн лет, метаморфизованные совместно с вмещающими породами в условиях амфиболитовой фации, и популяция метаморфогенного циркона с возрастами в интервале 400-370 млн лет (SIMS, Wang et al, 2006). В Восточном Казахстане северо-западного продолжения ЮАМП (рис. 1) в сдвиговых зонах, ограничивающих тектонические пластины встречаются рассланцованные гранитоиды, с возрастом $226 \pm 9$ млн лет (ID-TIMS, Козаков и др., 2011). При этом оценка возраста метаморфизма по циркону ультраметагенных гранатовых

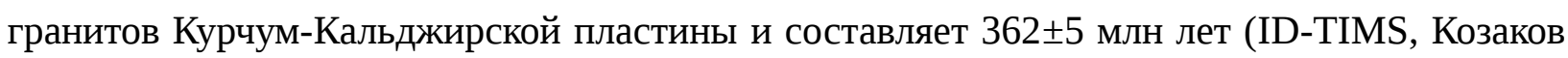
и др., 2011). Надо отметить, что в этой пластине метаморфизм происходил в условиях 
андалузит-силлиманитовой фациальной серии и ранний эпизод метаморфизма не фиксируется, что отличает ее от остальных пластин ЮАМП.

В целом, в пределах восточной части ЮАМП кристаллические породы, были сформированы к началу раннего карбона и позднее не вовлекались в процессы высокотемпературного регионального метаморфизма. Развитие сдвиговых зон не фиксируется в пермских гранитоидах. Однако в северо-западном продолжении пояса в Китайском Алтае и Восточном Казахстане после завершения девонского метаморфизма в пермских гранитоидах известны, главным образом, низкотемпературные метаморфические преобразования.

Метабазиты гашуннурского комплекса. Внедрение даек гашуннурского комплекса происходило в интервале между ранним и поздним эпизодами метаморфизма - 380-375 млн лет. Они в разных масштабах развиты во многих тектонических пластинах ЮАМП. Наиболее широко они представлены в Цэлской пластине (рис. 4), где образуют дайковые поля и рои метабазитов (рис. 5а, б). В районе сомона Цэл по геохимическим характеристикам они сходны с базальтами срединно-океанических хребтов или океанических плато, а в юго-восточной части Цэлской пластины их составы смещены в область базальтов вулканических дуг. Sm-Nd изотопные исследования также дают аналогичные различия в характеристиках источников их расплавов (Козаков и др., 2019).

Структуры Цэлской тектонической пластины. В Цэлской тектонической пластине возрастные рубежи формирования структур были установлены на основе корреляции с этапами развития структур Бодончинской и Цогтской тектонических пластин, расположенных в северо-западном и юго-восточном продолжении ЮАМП(рис. 2). В Цэлской пластине были получены оценки значений возраста циркона методом LA ICP MS 550-460 и 430-350 млн лет (Burenjargal et al., 2014, Hanzl et al.,2016), однако они не дают возможности установить положение датированных объектов по отношению к этапам структурно-метаморфического развития ЮАМП.

Складчатые структуры раннего эпизода метаморфизма $\left(\mathrm{M}_{1}\right)$ в Цэлской пластине и, как правило, в других пластинах имели изначально субмеридиональную ориентировку (в современной структуре), то есть несовпадающую с главными картируемыми северозападными и широтными структурами тектонических пластин ЮАМП (Козаков, 1986; Козаков и др. 2007, 2011). Это фиксирует положение шарниров реликтовых складок и линейности (рис. 4). Наложение регионального метаморфизма позднего эпизода $\left(\mathrm{M}_{2}\right)$ сопровождалось образованием на ранней стадии пологих структур: лежачих изоклинальных складок и новообразованной пологой сланцеватости и метаморфической полосчатости, паралельной их осевым поверхностям (рис. 6). Как правило наложенный 
метаморфизм не сопровождался мигматитообразованием; иногда фиксируется фельдшпатизация. Структуры и минеральные парагенезисы раннего эпизода ( $\left.\mathrm{M}_{1}\right)$ сохраняются только как реликты (рис. 5в), разделенные зонами рассланцевания и в большинстве случаев затушевываются. Главные картируемые структуры Цэлской пластины определяют прямые изоклинальные складки субширотного простирания позднего эпизода $\left(\mathrm{M}_{2}\right)$ (рис. 2) и регионально развитая кристаллизационная сланцеватость, параллельная их осевым поверхностям (Козаков и др., 2007, 2011). В Цогтской Барлагинской и Бодончинской пластинах они имеют северо-западную ориентировку, то есть они в основных чертах подчиняются доминирующему простиранию ЮАМП (рис. 2). Рубежи возрастного интервала формирования структур Цэлской пластины не были установлены.

Для оценки возраста метаморфизма $\mathrm{M}_{2}$ были опробованы синметаморфические кварцевые диориты (проба 8136) (рис. 4). Синметаморфичекое положение кварцевых диоритов с возрастом $374 \pm 2$ млн лет определяется наложением кристаллизационной сланцеватости (по биотиту, реже с роговой обманкой), параллельной осевым поверхностям главных картируемых изоклинальных складок позднего этапа метаморфизма, регионально развитым во вмещающих породах (биотитовых гнейсах с пластами амфиболитов). Наложение данной кристаллизационной сланцеватость показывает, что данные кварцевые диориты ко времени ее наложения были уже закристаллизованы как и дайковые тела плагиогранитов поздней фазы. Пологие структуры (кристаллизационная сланцеватость и лежачие складки первого этапа метаморфизма $\mathrm{M}_{2}$ ), которые регионально наложены на дайки гашуннурского комплекса и мигматиты раннего эпизода метаморфизма $\left(\mathrm{M}_{1}\right)$, в кварцевых диоритах не проявлены (рис. 6). То есть, их внедрение происходило после образования пологих структур раннего этапа, но до образования прямых складок и регионально развитой кристаллизационной сланцеватости позднего эпизода метаморфизма $\left(\mathrm{M}_{2}\right)$. Запрокидывание последних в Цэлской пластине и, соответственно, кристаллизационной сланцеватости в массиве на север связано с надвигами происходившими в ходе сочленения метаморфических пород с толщами пород раннего палеозоя южной окраины каледонского палеоконтинента (рис. 4). Эти соотношения практически совпадают с установленными для массива Эхний-ус Бодончинской пластины (371 \pm 2 млн лет) - внедрение между первым и вторым этапами метаморфизма $\mathrm{M}_{2}$. В Бодончинской, Барлагинской и Цогтской пластинах зоны их сочленения с толщами северного обрамления имеют субвертикальную ориентировку, в меньшей степени осложненную надвигами. Интрузивные породы, связанные с этим метаморфизмом, в разной степени рассланцованы и, сланцеватость в них совпадает с ориентировкой 
структур вмещающих метаморфических пород.

Установление верхней возрастной границы интервала метаморфизма $\mathrm{M}_{2}$ определяют массивные постметаморфические субщелочные граниты (проба 8200) юго-восточной части Цэлской пластины. Во вмещающих их толщах широко представлены мигматизированные породы раннего этапа метаморфизма $\mathrm{M}_{1}$, анатектические гранитоиды и прорывающие их метабазиты гашуннурского комплекса, образующие дайковые рои (рис. 4). Данные граниты, фактически, пересекают дайковое поле метабазитов гашуннурского комплекса и являются более поздними по отношению к метаморфизму $\mathrm{M}_{2}$. На всем протяжении они не содержит признаков рассланцевания и термального воздействия (формирование оболочек) на четко выраженную осциляторную зональность цирконов магматического генезиса. В тоже время в породах рамы непосредственно у контакта на всем протежении фиксируется метаморфизм амфиболитовой фации. Вовлечение пластового тела данных гранитов в открытую складку (рис. 4) может быть связано с более поздними постметаморфическими сдвиговыми деформациями, происходившими в ходе сочленения Цэлской тектонической пластины с толщами герцинид южного обрамления.

\section{Результаты U-Pb геохронологических исследований циркона гранитоидов Цэлской}

\section{тектонической пластины}

Методика исследований. Выделение циркона проводилось по стандартной методике с использованием тяжелых жидкостей. Выбранные для U-Pb геохронологических исследований кристаллы циркона (или их фрагменты) подвергались многоступенчатому удалению поверхностных загрязнений в спирте, ацетоне и 1 M HNO. При этом после каждой ступени эти кристаллы промывались особо чистой водой. Химическое разложение циркона и выделение $\mathrm{U}$ и $\mathrm{Pb}$ выполнялось по модифицированной методике T.E. Кроу (Krogh, 1973). В некоторых случаях для уменьшения степени дискордантности использовалась аэроабразивная обработка (Krogh, 1982). Изотопные анализы выполнены на многоколлекторном масс-спектрометре TRITON TI как в статическом режиме, так и при помощи счетчика ионов. Для изотопных исследований использовался трассер ${ }^{235} \mathrm{U}-{ }^{202} \mathrm{~Pb}$. Точность определения содержаний $\mathrm{U}$ и $\mathrm{Pb}$ составила 0.5\%. Холостое загрязнение не превышало 15 пг $\mathrm{Pb}$ и 1 пг $\mathrm{U}$. Обработка экспериментальных данных проводилась при помощи программам «PbDAT» (Ludwig, 1991) и «ISOPLOT» (Ludwig, 2003). При расчете возрастов использованы общепринятые значения констант распада урана (Steiger, Jager, 1976). Поправки на обычный свинец введены в соответствии с модельными величинами (Stacey, Kramers, 1975). Все ошибки приведены на уровне 2-б.

Из кварцевых диоритов пробы 8136 выделен акцессорный циркон, который 
представлен полупрозрачными бесцветными или желтоватыми идиоморфными, реже субидиоморфными кристаллами. В пробе присутствуют короткопризматические, призматические, длиннопризматические (до игольчатых) кристаллы. Размер индивидов изменяется от 50 до 400 мкм, а коэффициент удлинения - от 1.0 до 7.0. Огранение представлено комбинацией призмы $\{100\}$ и дипирамид $\{101\},\{201\}$ (рис. 7a I-IV).

Изучение особенностей внутреннего строения зерен осуществлялось при помощи оптического микроскопа и катодолюминесценции. Этот циркон обладает четко проявленным тонкозональным внутренним строением (рис. 7a V-VIII), в нем присутствуют скопления мелких пылевидных газово-жидких и минеральных рудных включений. Отдельные кристаллы содержат реликты унаследованных ядер (рис. 7а II).

Для геохронологических исследований из размерных фракций 50-100 и 150-200 мкм были выбраны четыре микронавески наиболее «чистых» и идиоморфных кристаллов циркона (табл. 1). Изученный циркон характеризуется незначительной (1.8-4.8 \%) прямой возрастной дискордантностью. При этом положение фигуративных точек этих навесок циркона на диаграмме с конкордией (рис. 8а) указывает на то, что возрастная дискордантность вызвана как современными потерями (№ 1-3, табл.1), так и присутствием унаследованного свинца (№ 4, табл.1). Среднее значение возраста $\left({ }^{206} \mathrm{~Pb} /{ }^{207} \mathrm{~Pb}\right)$ изученного циркона (№ 1-3) составляет 374 \pm 2 млн лет $(\mathrm{CKBO}=1.8)$ и может быть использовано в качестве оценки возраста его кристаллизации.

Циркон из гранитоидов (проба 8200) представлен идиоморфными и субидиоморфными кристаллами призматического габитуса с Кудл. = 1.8-3.6. Основные простые формы, участвующие в огранении, представлены призмами $\{100\}$, $\{110\}$ и дипирамидами $\{101\},\{111\},\{401\}$ (рис. 76 I-IV). Кристаллы прозрачные и полупрозрачные, светло-желтые и бесцветные. Внутреннее строение характеризуется тонкой магматической зональностью (рис. 76 V-VIII) и наличием большого количества газово-жидких и минеральных пылевидных и игольчатых включений.

$\mathrm{U}-\mathrm{Pb}$ геохронологические исследования проведены для наиболее прозрачного и идиоморфного циркона из трех микронавесок, отобранных из размерных фракций 50-75 и 75-100 мкм. Дискордия, рассчитанная для трех точек состава циркона (табл. 1), имеет верхнее пересечение с конкордией, соответствующее возрасту $360 \pm 5$ млн лет (CKBO=1.0) (рис. 8б). Морфологические особенности циркона указывают на его магматическое происхождение и полученную оценку возраста можно рассматривать как оценку возраста формирования данных гранитоидов.

\section{Обсуждение результатов}

Полученные данные о возрасте син- и постметаморфических гранитоидов (374 2 и 
$360 \pm 5$ млн лет) дают возможность дать оценку возрастного интервала проявления позднего эпизода метаморфизма $\left(\mathrm{M}_{2}\right)$ в Цэлской тектонической пластине ЮАМП - 375360 млн лет. Значения возраста синметаморфических расслоенного габбро ранней фазы и трондьемитов поздней фазы массива Эхний-ус Бодончинской тектонической пластины находятся практически в этом же интервале. Близкие оценки возраста позднего эпизода метаморфизма установлены на всем протяжении ЮАМП: в Китайском Алтае $(373 \pm 2$ млн

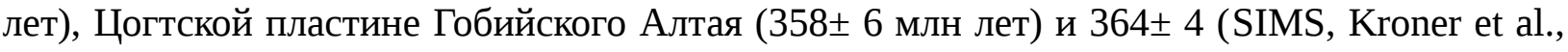

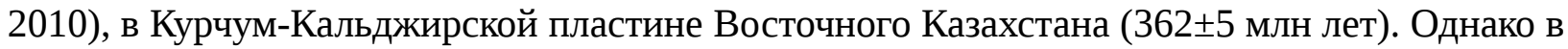
Курчум-Кальджирской пластине ранний эпизод метаморфизма, который проявлен в остальных тектонических пластинах ЮАМП, не фиксируется, а близкий по возрасту метаморфизм амфиболитовой фации происходил в условиях пониженного давления в отличии от остальных тектонических пластин, включая и смежные пластины Иртышской сдвиговой зоны Восточного Казахстана. Можно полагать, что в данный период КурчумКальджирская пластина была пространственно разобщена с главной зоной формирования ЮАМП. В современной структуре она отделена мощной зоной зеленосланцевых бластомилонитов от сопредельных Предгорненской, Чечекской и Маркакольской пластин, в которых известны парагенезисы амфиболитовой фации кианит-силлиманитовой фациальной серии.

Проявление раннего эпизода метаморфизма $\left(\mathrm{M}_{1}\right)$ также известно во многих тектонических пластинах практически на всем протяжении ЮАМП. Он был установлен в центральной части Цогтской тектонической пластины на рубеже около 385 млн лет (ID TIMS, Бибикова и др., 1992) и на ее юго-восточном продолжении - $397 \pm 3$ и $396 \pm 3$ млн лет (SIMS, Demoux et al., 2009, Kröner et al., 2010). В Цэлской пластине для гнейсогранитов получена близкая оценка возраста $385 \pm 7$ млн лет (LA ICP MS, Burenjargal et., al. 2014). В Бодончинской пластине на проявление раннего и позднего эпизодов метаморфизма указывает с одной стороны присутствие ксенолитов мигматизированных амфиболитов в габбро-диоритах массива Эхний-ус с возрастом (371 \pm 2 млн лет), а с другой - присутствие в парагнейсах метаморфогенных цирконов с возрастами $389 \pm$ 3, 394 \pm 1 и $374 \pm 1$ млн лет (Jiang et al., 2012). Последнее значение практически совпадает с оценкой возраста позднего эпизода метаморфизма $\left(\mathrm{M}_{2}\right)$. В гнейсах и кристаллических сланцах Согринской и Бухтарминской тектонических пластин Восточного Казахстана северо-западного продолжения ЮАМП среди метаморфических пород амфиболитовой фации повышенного давления присутствуют более ранние реликтовые парагенезисы амфиболитовой фации андалузит-силлиманитовой фациальной серии (Ермолов и др., 1984). 
Необходимо подчеркнуть, что метаморфические преобразования установленных эпизодов не являются стадиями развития единого цикла метаморфизма, происходившего в интервале около 390-360 млн лет, а разделены относительно кратковременной стадией стабилизации ( 380-385 млн лет), что предполагает смену тектонических обстановок. В первую очередь это фиксирует, внедрение даек базитов гашуннурского комплекса, имеющих секущие соотношения с гранитами, завершающими процессы раннего эпизода метаморфизма $\mathrm{M}_{1}$. Граниты, образуют массивы, а также секущие жильные образования в мигматитах, после чего совместно с ними вовлекаются в структурно-метаморфические преобразования в ходе повторного метаморфизма $\left(\mathrm{M}_{2}\right)$ в условиях амфиболитовой фации (Козаков и др., 2007, 2019).

Рассматривая возможную тектоническую обстановку формирования ЮАМП надо отметить, что к концу кембрия - началу ордовика был сформирован раннекаледонский палеоконтинент и по его южной окраине установился режим пассивной окраины. (Руженцев, Поспелов, 1992). В раннем-среднем палеозое произошло преобразование пассивной окраины в активную и формирование аккреционного клина. Спектр возрастов детритовых цирконов указывает на значительную роль раннепалеозойских пород в источнике осадков, но также свидетельствует о подчиненном участии более древних комплексов - ранне- и позднедокембрийских (Jiang et al., 2011). В Цэлской тектонической пластине ядра детритовых цирконов из пелитовых гнейсов показывают диапазон возрастов 455-2600 млн лет с доминирующими популяциями около 490-520 млн лет (LA ICP-MS Burenjargal et al., 2014; Jiang et al., 2011). Изотопные характеристики Pb и Nd средне- и позднепалеозойских гранитоидов Монгольского и Гобийского Алтая также отражают неоднородность их источников, которыми являлись метатерригенные породы новообразованного аккреционного клина. Они могли формироваться как продукты разрушения пород с $\mathrm{Pb}$ и $\mathrm{Nd}$ изотопными характеристиками островодужных комплексов Озёрной зоны, а также ранне- и позднедокембрийских террейнов южного обрамления Сибирской платформы - источников метаморфических пород с древнекоровыми изотопными характеристиками (Саватенков и др., 2020).

В конце раннего и в среднем девоне в пределах Южно-Монгольского палеоокеана формируется система островных дуг и задуговых прогибов, что характеризует быстрый рост ювенильной коры (Ярмолюк и др., 2007). К середине девона прекратился спрединг во всех океанических бассейнах и в результате действия протяженных зон субдукции вдоль Сибирского континента и Казахстана началось их активное закрытие.

Результаты проведенных исследований позволяют рассмотреть следующую последовательность формирования моно- и полиметаморфических комплексов ЮАМП 
(рис. 9 ). В раннем девоне в обрамлении каледонского палеоконтинента в океанических бассейнах начались процессы конвергенции, а в окраине каледонского палеоконтинента произошел переход к режиму активной окраины. С этим процессом связан ранний эпизод регионального метаморфизма $\left(M_{1}\right)$ в интервале около 390-380 млн лет. Условия этого метаморфизма (повышенная температура и пониженное давление) предполагают пологую субдукцию горячей океанической плиты при близком расположении оси спрединга к окраине каледонского Сибирского палеоконтинента (рис. 9а). В ходе субдукции спрединговый центр перемещался в направлении новообразованной активной окраины каледонского палеоконтинента и впоследствии был субдуцирован под окраину континента (рис. 9б). С его прохождением под краем континента могло быть связано развитие рифтогенных процессов в пределах последнего субдукционного процесса, кратковременная стабилизация и внедрение постметаморфических гранитоидов (по отношению к структурам раннего эпизода метаморфизма $\mathrm{M}_{1}$. C погружением спредингового хребта под край континента в интервале 380-370 млн лет может быть связано формирование роев даек гашуннурского комплекса.

Позднедевонский эпизод (370-360 млн лет) метаморфизма повышенного давления $\left(\mathrm{M}_{2}\right)$ коррелируется с продолжением аккреции среднепалеозойских островодужных комплексов блоков Южной Монголии (Ярмолюк и др., 2007). С ним связано формирование тектонических пластин различного порядка (рис. 2), а также становление их внутренней чешуйчатой структуры. Возобновление субдукционного процесса привело к развитию регионального метаморфизма повышенного давления, с которым связана переработка метаморфических пород раннего эпизода, а также завершающих его гранитоидов и даек гашуннурского комплекса.

K середине девона прекратился спрединг во всех океанических бассейнах, и в результате действия протяженных зон субдукции вдоль Сибирского палеоконтинента и Казахстана началось их активное закрытие. Можно полагать, что субдукционные зоны погружались под новообразованную окраину Северо-Азиатского палеоконтинента и систему внутриокеанических островных дуг со смещением их в сторону океана (Руженцев, Поспелов, 1992). Развитие возникшей здесь активной континентальной окраины, начавшееся около 400 млн лет назад, завершилось к началу раннего карбона. Обь-Зайсанский и Южно-Монгольский океаны превратились в остаточные океанические бассейны (Руженцев и др., 1991), а в конце среднего-начале позднего карбона ОбьЗайсанский и Южно-Монгольский океаны полностью закрылись.

В тектонических пластинах Монгольского Алтая ранний метаморфизм $\mathrm{M}_{1}$, как правило, установлен в относительно узкой полосе их южных частей. Структурно- 
метаморфические преобразования, связанные с метаморфизмом $\mathrm{M}_{2}$, проявлены как наложенные в ранее метаморфизованных породах, но также и в породах, в которых не фиксируется парагенезисов или структур, связанных с более ранним метаморфизмом. То есть, сочленение этих образований происходило до начала метаморфизма повышенного давления $\left(\mathrm{M}_{2}\right)$. Метаморфические преобразования $\mathrm{M}_{2}$ были наложены как на породы, достигающие уровня высокотемпературной амфиболитовой и гранулитовой фации, так и на породы более низких степеней метаморфизма $\mathrm{M}_{1}$.

Изменение термодинамического режима метаморфизма - переход от режима пониженного давления к повышенному в интервалах “против движения часовой стрелки”, может быть связано с проявлением стабилизации и, соответственно, охлаждения сформированных метаморфических образований. В ходе продолжения аккреционноколлизионного процесса и возобновления субдукции по мере их перемещения от края каледонского палеоконтинента могло произойти изменение термодинамического режима (Лиханов, 2020), возможно, вследствие изменения угла наклона субдукционных зон.

Следует подчеркнуть, что реликтовые структуры, в которых устанавливается проявление процессов раннего эпизода метаморфизма $\mathrm{M}_{1}$, а также дайки гашуннурского комплекса, как правило, изначально имели несовпадающую (субмередиональную) ориентировку с главными картируемыми структурами, сформированными в ходе позднего эпизода метаморфизма $\mathrm{M}_{2}$ (рис. 2). На начальной стадии последнего (после внедрения даек гашуннурского комплекса) произошло региональное выполаживание структур раннего эпизода - формирование лежачих складок и пологой кристаллизационной сланцеватости (рис. 6а). Это может быть связано с развитием надвигов в глубинных сечениях земной коры - уровня амфиболитовой и гранулитовой фации. После этого были образованы регионально развитые прямые изоклинальные складки и кристаллизационная сланцеватость практически во всей полосе выходов тектонических пластин ЮАМП, что фиксируется в его современной структуре (рис. 6б). При этом данные структурнометаморфические преобразования не находят отражения породах в породах его обрамления. В частности, в породах венда-кебрия, контактирующих с метаморфическими породами Цэлской тектонической пластины нет признаков структурно-метаморфической переработки (Маркова, Федорова, 1971). Можно полагать, что положение тектонических пластин ЮАМП в современой структуре, обусловлено более поздними сдвиговыми деформациями. В последних проявлены милонитизация или рассланцевание зеленосланцевой, а в ряде случаев амфиболитовой фации. Исключением являются тектонические пластины северо-западной части Китайского Алтая, в которых установлены палеозойские гранитоиды с возрастом 462+10 млн лет, метаморфизованные совместно с 
вмещающими породами в условиях амфиболитовой фации, а в данных гранитоидах установлены также метаморфогенные цирконы с возрастами в интервале 400-370 млн лет (SIMS, Wang et al, 2006). То есть региональный метаморфизм ЮАМП в данном случае был проявлен и в толщах раннего палеозоя. В целом совмещение метаморфических пород с и толщ венда-раннего палеозоя северного обрамление происходило по постметаморфическим надвигам и было осложнено в ходе сдвиговых деформаций.

\section{Заключение}

Геохронологические данные о возрасте син- и постметаморфических гранитоидов (374 \pm 2 и $360 \pm 5$ млн лет) дают возможность дать оценку возрастного интервала проявления позднего эпизода метаморфизма повышенного давления $\left(\mathrm{M}_{2}\right)$ в Цэлской тектонической пластине ЮАМП - 375-360 млн лет. Они показывают практически одинаковые значения с возрастом метаморфизма, проявленного в юго-восточном и северо-западном направлении в тектонических пластинах Гобийского и Монгольского Алтая. Полученные и опубликованные геохронологические и геологические данные дают основание для корреляции данных процессов метаморфизма с установленными в структурах Китайского Алтая и Восточного Казахстана (Иртышской сдвиговой зоне) и связывать с развитием единого герцинского метаморфического пояса.

Структурно-геологические, геохронологические и петрологические данные дают основание для установления более раннего эпизода высокотемпературного метамофизма умеренно-пониженного давления в тектонических пластинах Монгольского и Гобийского Алтая в интервале 395-385 млн лет. В пределах Китайского Алтая и Восточного Казахстана, установлена сходная последовательность процессов метаморфизма, но надежных геохронологических данных для установления раннего эпизода метаморфизма пока нет.

Формирование ЮАМП отражает основные этапы развития девонской континентальной окраины каледонского палеоконтинента. Субдукция молодой океанический плиты вблизи оси спрединга обусловила ранний эпизод метаморфизма $\mathrm{M}_{1}$ в интервале около 390-380 млн лет. Погружение спредингового хребта под активную окраину обрамления каледонского палеоконтинента и открытие астеносферного окна инициировало перерыв в развитии субдукционной зоны и, соответственно, перерыв в развитии метаморфизма раннего эпизода в интервале около 380-375 млн лет. Поздний эпизод метаморфизма $\mathrm{M}_{2}$ в интервале около 370-360 млн лет связан с продолжением аккреционно-коллизионного процесса причленения островодужных комплексов ЮжноМонгольского и Обь-Зайсанского палеоокеанических бассейнов к Алтайской окраине Сибирского и Казахстанского палеоконтинентов. Можно предположить, что изменение 
ориентировки структур при переходе к позднему эпизоду метаморфизма связано с проявлением стабилизации и, соответственно, охлаждения сформированных к этому рубежу метаморфических пород. Возобновление аккреционно-коллизионного процесса и начало метаморфизма позднего эпизода метаморфизма, возможно происходило при сочленении и совместной деформации пород разной компетентности консолидированных метаморфических пород и пород террегеннно-вулканогенных комплексов, ранее не вовлеченных в процессы метаморфизма.

В целом становление ЮАМП связано с развититием герцинского ЮжноМонгольского палеоокеанического бассейна, в котором активное многоэтапное развитие проявлено в обрамлении каледонского палеоконтинента. Однако положение тектонических пластин - фрагментов ЮАМП в современной структуре обусловлено более поздними сдвиговыми деформациями, оторванными во времени от проявленных в них процессов регионального метаморфизма, как это показано для обрамления Сибирской платформы (Метелкин, 2012).

Авторы признательны рецензентам, за конструктивные предложения и замечания, позволившие улучшить изложение представленного в статье материала. Работа выполнена при финансовой поддержке РФФИ (проект № 20-05-00297). 


\section{СПИСОК ЛИТЕРАТУРЫ}

Бибикова Е.В., Кирнозова Т.И., Козаков И.К., Котов А.Б., Неймарк Л.А., Гороховский Б.М., Шулешко И.М. Полиметаморфические комплексы южного склона Монгольского и Гобийского Алтая: результаты уран-свинцового датирования // Геотектоника, № 2, 1992, с. 104-112.

Диденко А.Н., Моссаковский А.А., Печерский Д.М., Руженцев С.В., Самыгин С.Г., Хераскова T.H. Геодинамика палеозойских океанов Центральной Азии // Геология и геофизика. 1994. Т. 35, № 7/8. C. 59-75.

Ермолов П.В., Паталаха Е.И., Ефимов И.А., Полянский Н.В., Пономарева А.П., Найденов Б.М. Хохлов П.И. Метаморфические комплексы и некоторые черты тектоники Зайсанской складчатой системы и рудного Алтая // Геотектоника. 1984. № 4 С. 61-74.

Козаков И.К. Докембрийские инфраструктурные комплексы Монголии. Л.: Наука, 1986. 144 c.

19. Козаков И.К., Глебовицкий В.А., Бибикова Е.В. .Азимов П.Я, Кирнозова Т.И. Геодинамическая позиция и условия формирования гранулитов герцинид Монгольского и Гобийского Алтая // Доклады Академии наук, 2002, том 386, № 1, с. 82-87.

Козаков И.К., Сальникова Е.Б., Диденко А.Н., Ковач В.П., Федосеенко А.М., Яковлева С.З. Возраст и геодинамическая обстановка формирования высокотемпературных метаморфических комплексов Южно-Монгольского пояса // Геология и геофизика, 2004, том 45, № 4, с.519-524.

Козаков И.К., Ковач В.П., Бибикова Е.В., Кирнозова Т.И., Загорная Н.Ю., Плоткина Ю.В., Подковыров В.Н. Возраст и источники гранитоидов зоны сочленения каледонид и герцинид ЮгоЗападной Монголии: геодинамические следствия // Петрология, 2007. Т. 15. № 1. С. 133-159.

Козаков И.К., Кирнозова Т.И., Плоткина Ю.В. Возраст источника метатерригенных пород Южно-Алтайского метаморфического пояса // Стратиграфия. Геологическая корреляция. 2009. Т. 17. № 1. C. 41-48.

Козаков И.К., Диденко А.Н., Азимов П.Я., Кирнозова Т.И., Ковач В.П., Сальникова Е.Б., Эрдэнэжаргал Ч. Геодинамические обстановки и условия формирования кристаллических комплексов Южно-Алтайского и Южно-Гобийского метаморфических поясов // Геотектоника. 2011. № 3. С. 7-30.

Козаков И.К., Козловский А.М., Ярмолюк В.В., Кирнозова Т.И., Фугзан М.М., Оюунчимэг Ц. , Эрдэнэжаргал Ч. Геодинамическая обстановка формирования поли- и монометаморфических комплексов Южно-Алтайского метаморфического пояса, Центрально-Азиатский складчатый пояс. Петрология. 2019. Том 27., № 3. С. 233-257.

И.И. Лиханов И.И. Метаморфические индикаторы геодинамических обстановок коллизии, растяжения и сдвиговых зон Земной коры //Петрология, 2020, Т. 28, № 1, с. 4-22.

Маркова Н.Г., Федорова М.Е. О связи метаморфизма с тектонической структурой на примере Юго-Западной Монголии // Проблемы теоретической и региональной тектоники. 1971. С. 104-114.

Метелкин Д.В. Эволюция структур Центральной Азии и роль сдвиговой тектоники по палеомагнитным данным. Новосибирск: ИНГГ СО РАН, 2012. 460 с. 
Моссаковский А.А., Руженцев С.В., Самыгин С.Г., Хераскова Т.Н. Центрально-Азиатский складчатый пояс: геодинамическая эволюция и история формирования // Геотектоника. 1993. №. 6. C. 3-32.

Полянский О.П., Сухоруков В.П., Травин А.В. и др. Тектоническая интерпретация термохронологических данных и Р-Т параметров метаморфизма пород зонального комплекса Бодончин (Монгольский Алтай) // Геология и геофизика. 2011. Т. 52. С. 1256-1275.

Руженцев С.В., Бадарч Г., Вознесенская Т.А., Маркова Н.Г. В кн. Эволюция геологических процессов и металлогения Монголии. М. Наука. 1990. С.111-117.

Руженцев С.В., Поспелов И.И. Южно-Монгольская варисская складчатая система // Геотектоника. 1992. № 5. С. 45-62.

Саватенков В.М., Козловскийс А.М., , Ярмолюкс В.В., Руднев С.Н., Оюунчимэг Ц. Рb и $\mathrm{Nd}$ Изотопная Систематика Гранитоидов Озёрной Зоны, Монгольского и Гобийского Алтая как Отражение Процессов корообразования В Центрально-Азиатском орогенном поясе // Петрология. 2020. T. 28, № 5, C. 451-467.

Сухоруков В.П. Состав и условия формирования андалузит-кианит-силлиманитовых сегрегаций в метаморфических породах Целского блока (Монгольский Алтай) // Геология и геофизика. 2007. Т. 48. № . С. 478-482.

Сухоруков В.П., Полянский О.П., Крылов А.А., Зиновьев С.В. Реконструкция Р-Т тренда метаморфизма глиноземистых сланцев Цогтского блока (Монгольский Алтай) на основании зональности граната // Петрология. 2016. Т. 24. С. 441-466.

Ярмолюк В.В., Коваленко В.И., Ковач В.П., Рыцк Е.Ю., Козаков И.К., Котов А.Б., Сальникова Е.Б. Ранние стадии формирования Палео-Азиатского океана: результаты геохронологических, изотопных и геохимических исследований позднерифейских и вендкембрийских комплексов Центрально-Азиатского складчатого пояса // Доклады академии наук, 2006, том 410, № 5, с. 1-7.

Ярмолюк В.В., Ковач В.П., Коваленко В.И., Терентьева Л.Б., Сальникова Е.Б., Козаков И.К., Котов А.Б., Энжин Г. Изотопный состав коры герцинид Южной Монголии: к обоснованию герцинского этапа ювенильного корообразования // Доклады академии наук, 2007, том 416, № 6, с. 804-809.

Burenjargal U, Okamoto A, Kuwata ni T, Sakata S, Hirata T, Tsuchiya N (2014) Thermal evolution of the Tseel Terrane, SW Mongolia and its relation to granitoid intrusions in the Central Asian Orogenic Belt. J Metamorph Geol 32: 765-790.

Demoux A., Kröner A., Hegner E., Badarch G. Devonian arc-related magmatism in the Tseel terrane of SW Mongolia: chronological and geochemical evidence // J. Geol. Soc. Lon. 2009. V. 166. P. 459-471.

Hanzl P., Schulmann K., Vojtmch Janouљek V., Ondrej Lexa O., Hrdliukov K, Jiang Yi., Buriбnek D., Battushig Altanbaatar B., Ganchuluun T., Erban V. Making continental crust: origin of Devonian orthogneisses from SE Mongolian Altai // Journal of Geosciences, 61 (2016), 25-50. 
Jiang Y, Sun M, Zhao G, Yuan C, Xiao W, Xia X, Long X, Wu F (2011) Precambrian detrital zircons in the Early Paleozoic Chinese Altai: their provenance and implications for the crustal growth of Central Asia. // Precambr Res 189: 140-154

Jiang Y., Sun M., Kröner A. Tumurkhuu D., Long X., Zhao GCю, Yuan C, Xiao WJ. The highgrade Tseel terrane in SW Mongolia: An early Paleozoic arc system or a Precambrian sliver? // Lithos. 2012. V. 142-143. P. 95-115.

Krogh T.E. A low-contamination method for hydrothermal decomposition of zircon and extraction of $\mathrm{U}$ and $\mathrm{Pb}$ for isotopic age determination // Geochim. et cosmochim. acta., 1973. V. 37. P. 485-494.

Krogh T.E. Improved accuracy of U-Pb zircon by the creation of more concordant systems using an air abrasion technique // Geochim. Cosmochim. Acta., 1982. V. 46. P. 637-649.

Kröner A., Lehmann J., Schulmann K., Demoux A., Lexa O., Tomurhuu D., Štípská P., Liu D., Wingate MTD (2010). Devonian orthogneisses from SE Mongolian Altai Lithostratigraphic and geochronological constraints on the evolution of the Central Asian Orogenic Belt in SW Mongolia: Early Paleozoic rifting followed by Late Paleozoic accretion. Amer J Sci 310: 523-574

Ludwig K.R. PbDat for MS-DOS, version 1.21 // U.S. Geol. Survey Open-File Rept. 88-542. 1991b. 35p.

Ludwig K.R. Isoplot 3.70. A Geochronological Toolkit for Microsoft Excel // Berkeley Geochronology Center Spec., 2003. V.4.

Stacey J.S., Kramers I.D. Approximation of terrestrial lead isotope evolution by a two-stage model // Earth Planet. Sci. Lett. 1975. V. 26. № 2. P. 207-221.

Steiger R.H., Jaeger E. Subcomission of Geochronology: convention of the use of decay constants in geo- and cosmochronology // Earth Planet. Sci. Lett. 1976. V. 36. № 2. P. 359-362.

Wang T., Hong D., Jahn B. Tong Yi., Wang Ya., Han B.,Wang Xi. . Timing, Petrogenesis, and Setting of Paleozoic Synorogenic Intrusions from Altay Mountains, Northwest China: Implicatioons for the Tectonic Evolution of Accretionary Orogen // The Journal of Geology. 2006. V. 114. P. 735-751.

Windley B.F., Kröner A. Guo Ji., Qu G., Li Y., Zhang Ch. Neoproterozoic to Paleozoic Geology of the Altai Orogen, NW China: New Zircon Age Data and Tectonic Evolution // J. Geology. 2002. V. 110. P. 719-737.

Zheng Ch. Q., Kato T., Enami M., Хи u. CHIME monazite ages of metasediments from Altai orogen in northwestern Cina: Devonian and permian ages af metamorphism and their significance // Island Arc. 2007. V. 16. P. 598-604. 


\section{ПОДПИСИ К РИСУНКАМ}

Рис. 1. Схема положения кристаллических пород Южно-Алтайского метаморфического пояса в структурах центрального сегмента Центрально-Азиатского складчатого пояса. Составлена с использованием (Моссаковский и др., 1993, Диденко и др., 1994, Козаков и др., 2004, 2011, 2019).

1 - древние платформы; 2 - структуры раннекаледонского супертеррейна Центральной Азии; 3 - структуры поздних каледонид; 4, 5 - линейные аккреционно-коллизионные пояса: 4 позднепалеозойские (герцинские), 5 - раннемезозойские (индосинийские); 6 - поля нерасчлененных позднепалеозойских и мезо-кайнозойских вулканитов; 7-9 - докембрийские террены: 7 - раннедокембрийские, 8 - неопротерозойские, 9 - неопротерозойские и палеозойским основанием; 10 - области выходов тектонических пластин Южно-Алтайского метаморфического пояса (390-360 млн. лет): 1 - сдвиговой зоны Восточного Казахстатна, 2 - Китайского Алтая, 3 Монгольского Алтая,4 - Гобийского Алтая; 11 - положение зоны Южно-Гобийского метаморфического пояса (230-220 млн. лет); 12 - главные тектонические границы.

Римскими цифрами показаны докембрийские террейны: I - Тувино-Монгольский, II Дзабханский и Сонгинский; III - Байдарикский, IV - Тарбагатайский

Рис. 2. Схема тектонического положения кристаллических комплексов Монгольского и Гобийского Алтая.

1 - герциниды Южно-Монгольского пояса; 2 - каледониды краевой части Северо-Азиатского палеоконтинента; 3 - ранние каледониды Озерной зоны; 4 - тектонические пластины кристаллических пород герцинского Южно-Алтайского метаморфического пояса; 5 посткинематические гранитоиды (поздний палеозой-ранний мезозой), 6 - глубинные разломы, разделяющие тектонические структуры (I -Булганский, II - Заалтайский); 7 - разломы; 8 положение объектов датирования (возраст в млн лет).

Цифры в кружках - тектонические пластины: 1 - Булганская, 2 - Бодончинская, 3 Барлагинская, 4 - Цэлская, 5 - Цогтская.

Рис. 3. Структуры раннего и позднего этапов метаморфизма в кристаллических комплексах Китайского Алтая (фото).

а - реликтовая структура мигматитов раннего эпизода метаморфизма $\left(\mathrm{M}_{1}\right)$; б рассланцованные мигматиты при наложении позднего эпизода метаморфизма $\left(\mathrm{M}_{2}\right)$; в - пегматиты с возрастом $373 \pm 2$ млн лет, завершающие метаморфизм позднего эпизода $\left(\mathrm{M}_{2}\right)$.

Рис. 4. Схема строения восточной части Цэлского блока. Составлена с использованием (Маркова, Федорова, 1971;. Козаков, 1986; Козаков и др., 2019).

1 - рыхлые отложения; 2 - песчаники, аргиллиты, известняки (девон); 3 биотитовые,биотит-хлоритовые сланцы с горизонтами мраморизованных известняков (силур); 4 вулканиты основного состава, шаровые базальты Озерной зоны (венд-нижний кембрий); 5-14 цэлский кристаллический комплекс 5 - толщи монометаморфической породной ассоциации (биотитовые, биотит-хлоритовые, гранат-биотитовые, амфиболовые гнейсы); 6-9 - толщи полиметаморфической породной ассоциации: 6 - биотитовые и двуслюдяные гнейсы, гранат- 
биотитовые гнейсы; 7 - толща переслаивания биотитовых гнейсов с известково-силикатными прослоями и мраморами; 8 - толща переслаивания мигматизированных амфиболитов и гнейсов; 9 - толща переслаивания гнейсов с известково-силикатными прослоями и амфиболитов, железометасоматитов с магнетитовыми рудами. 10-14 - метаморфизованные $\left(M_{1}\right)$ магматические породы: 10 - гнейсо-граниты раннего этапа метаморфизма ( $\mathrm{M}_{1}, \quad 385$ млн лет); 11 - гнейсодиориты и трондьемиты, 12-13 - метабазиты гашуннурского комплекса: 12 - массивы метагаббро, амфиболитов, с метаультрабазитами, 13 - рои даек метабазитов метапорфиритов; 14 постметаморфические субщелочные граниты $\left(\mathrm{M}_{2}, 360 \pm 5\right.$ млн лет); 15 - синметаморфические гнейсовидные кварцевые диориты (а), гранодиориты и трондьемиты (б) позднего этапа метаморфизма $\left(\mathrm{M}_{2}, 374 \pm 2\right.$ млн лет); 16 - жильные поля аплитов, гранитов и пегматитов (поздний палеозой); 17 - кристаллизационная сланцеватость, связанная с наложенным метаморфизмом $\left(\mathrm{M}_{2}\right)$; 18 - сдвиговые зоны, связанные с наложенным метаморфизмом $\left(\mathrm{M}_{2}\right) ; 19$ - ориентировка шарниров складок и линейность реликтовых структур раннего эпизода метаморфизма $\left(\mathrm{M}_{1}\right) ; 20$ ориентировка шарниров складок и линейность структур раннего эпизода метаморфизма $\left(\mathrm{M}_{2}\right) ; 21$ разломы, тектонические границы; 22 - положение геохронологических проб: 1 - проба 8136 - 374 млн лет; 2 - проба 8200 - 360 млн лет. (фото).

Рис 5. Метабазиты гашуннурского комплекса в структуре Цэлской тектонической пластины 5а - дайковое поле района Цэл-сомон; $5 б$ - деформированная дайка метабазита структур в зоне субвертикальных структур шарнир $\left(\mathrm{M}_{2}\right)$; 5в - реликтовая структура мигматитов амфиболитовой фации раннего эпизода метаморфизма $\mathrm{M}_{1}$ среди биотитовых гнейсов позднего эпизода метаморфизма.

Рис. 6. Схема последовательности формирования структур раннего и позднего эпизодов $\left(\mathrm{M}_{1}\right.$ и $\left.\mathrm{M}_{2}\right)$ регионального метаморфизма в Цэлской тектонической пластине.

Положение реликтовых структур раннего эпизода метаморфизма $M_{1}$ (a): 1 - реликтовые прямые субмеридиональные складки $\mathrm{M}_{1} ; 2$ - осевые поверхности прямых складок раннего эпизода метаморфизма $\mathrm{M}_{1}$; 3 - пологие структуры, параллельные осевым поверхностям лежачих складок первого этапа наложенного метаморфизма $\mathrm{M}_{2}$.

Последовательность формирования наложенных структур позднего эпизода метаморфизма $\mathrm{M}_{2}$ (б): 1 -складки раннего эпизода метаморфизма, смятые в лежачие складки наложенного метаморфизма $\mathrm{M}_{2}$; 2 - прямые складки;, 3 - субвертикальные плоскостные структуры, параллельные осевым поверхностям главных картируемых складок метаморфизма $\mathrm{M}_{2}$.

Рис. 7а. Микрофотографии кристаллов циркона из пробы 8136 (а) выполненные на сканирующем электронном микроскопе TESCAN VEGA 3: I-IV - в режиме вторичных электронов; V-VIII - в режиме катодолюминесценции.

Рис. 7б. Микрофотографии кристаллов циркона из пробы 8200, выполненные на сканирующем электронном микроскопе TESCAN VEGA 3: I-IV - в режиме вторичных электронов; V-VIII - в режиме катодолюминесценции.

Рис. 8. Диаграмма с конкордией для цирконов из пробы 8136 (а) и 8200 (б). Номера точек 
соответствуют порядковым номерам в таблице 1.

Рис. 9. Схема формирования моно- и полиметаморфичеких комплексов Монгольского и Гобийского Алтая в составе герцинского ЮАМП с использованием (Руженцев и др., 1991, Руженцев, Поспелов, 1992).

(а) - период ( 390-385 млн лет) развития процессов раннего эпизода метаморфизма $\mathrm{M}_{1}$ в акрреционной призме; (б) период стабилизации (380-375 млн лет), последующее продолжение акреционно-коллизионного процесса и развитие позднего эпизода метаморфизма(375-360 млн лет).

1 - континентальная кора южной окраины Северо-Азиатского палеоконтинента; 2 комплексы Южно-Монгольского палеоокеана; 3-5 - зоны развития процессов раннего эпизода метаморфизма $M_{1}$ различных сечений аккреционной призмы: 3 - области глубинных сечений (амфиболитовой, гранулитовой фации и ультраметаморфизма) ( 390-380 млн лет); 4 - сечение амфиболитовой фации (до изограды анатексиса), 5 - сечение низкотемпературного метаморфизма, 6 - зоны развития энсиматических дуг; 7 -зона спрединга; 8 - положение активной континентальной окраины; 9 - направление движения плит. 
Таблица 1. Результаты U-Pb изотопных исследований циркона гранитоидов Цэлской тектонической платины

\begin{tabular}{|c|c|c|c|c|c|c|c|c|c|c|c|c|c|}
\hline \multirow[b]{2}{*}{ Номер п/п } & \multirow{2}{*}{$\begin{array}{c}\text { Размерная фракция (мкм) и } \\
\text { характеристика циркона }\end{array}$} & \multirow{2}{*}{$\begin{array}{c}\text { Навеска, } \\
\text { мг }\end{array}$} & \multirow{2}{*}{$\begin{array}{c}\mathrm{Pb}, \\
\text { МКг/Г }\end{array}$} & \multirow{2}{*}{$\begin{array}{c}\mathrm{U}, \\
\mathrm{MKГ} / \Gamma\end{array}$} & \multicolumn{5}{|c|}{ Изотопные отношения } & \multirow{2}{*}{ Rho } & \multicolumn{3}{|c|}{ Возраст, млн. лет } \\
\hline & & & & & ${ }^{206} \mathrm{~Pb} /{ }^{204} \mathrm{~Pb}$ & ${ }^{207} \mathrm{~Pb} /{ }^{206} \mathrm{~Pb}^{\mathrm{a}}$ & ${ }^{208} \mathrm{~Pb} /{ }^{206} \mathrm{~Pb}^{\mathrm{a}}$ & ${ }^{207} \mathrm{~Pb} /{ }^{235} \mathrm{U}$ & ${ }^{206} \mathrm{~Pb} /{ }^{238} \mathrm{U}$ & & ${ }^{207} \mathrm{~Pb} /{ }^{235} \mathrm{U}$ & ${ }^{206} \mathrm{~Pb} /{ }^{238} \mathrm{U}$ & ${ }^{207} \mathrm{~Pb} /{ }^{206} \mathrm{~Pb}$ \\
\hline \multicolumn{14}{|c|}{ Проба 8136 (координаты: $45.61636^{\circ}$ с.ш., 95.737588º в.д.) } \\
\hline 1 & $150-200,403$. & 0.54 & 11.50 & 170 & 1701 & $0.0541 \pm 1$ & $0.3038 \pm 1$ & $0.4220 \pm 6$ & $0.0566 \pm 1$ & 0.92 & $357 \pm 1$ & $355 \pm 1$ & $373 \pm 1$ \\
\hline 2 & $150-200,35$ з. & 0.50 & 17.10 & 252 & 4198 & $0.0541 \pm 1$ & $0.3027 \pm 1$ & $0.4307 \pm 5$ & $0.0577 \pm 1$ & 0.95 & $364 \pm 1$ & $362 \pm 1$ & $376 \pm 1$ \\
\hline 3 & 150-200, 30 з.. & 0.49 & 12.60 & 179 & 1086 & $0.0540 \pm 1$ & $0.3009 \pm 1$ & $0.4322 \pm 6$ & $0.0581 \pm 1$ & 0.90 & $365 \pm 1$ & $364 \pm 1$ & $371 \pm 1$ \\
\hline 4 & 50-100, 20 з.. & 0.23 & 12.70 & 169 & 371 & $0.0551 \pm 1$ & $0.3014 \pm 1$ & $0.4329 \pm 9$ & $0.0570 \pm 1$ & 0.65 & $365 \pm 1$ & $357 \pm 1$ & $416 \pm 3$ \\
\hline \multicolumn{14}{|c|}{ Проба 8200 (координаты: $45.53546^{\circ}$ с.ш., $95.911027^{\circ}$ в.д.) } \\
\hline 5 & 75-100, 163. & $-*$ & $\mathrm{U} / \mathrm{Pb}=19$ & & 877 & $0.0540 \pm 2$ & $0.1433 \pm 1$ & $0.3650 \pm 7$ & $0.0490 \pm 1$ & 0.77 & $316 \pm 1$ & $308 \pm 1$ & $370 \pm 3$ \\
\hline 6 & 75-100, 203. & $-*$ & $\mathrm{U} / \mathrm{Pb}=19$ & & 1468 & $0.0543 \pm 1$ & $0.1340 \pm 1$ & $0.3685 \pm 7$ & $0.0492 \pm 1$ & 0.75 & $318 \pm 1$ & $310 \pm 1$ & $384 \pm 2$ \\
\hline 7 & 50-75, 203. & $-*$ & $\mathrm{U} / \mathrm{Pb}=17$ & & 3993 & $0.0538 \pm 1$ & $0.0852 \pm 1$ & $0.4210 \pm 4$ & $0.0568 \pm 1$ & 0.80 & $357 \pm 1$ & $356 \pm 1$ & $362 \pm 2$ \\
\hline
\end{tabular}

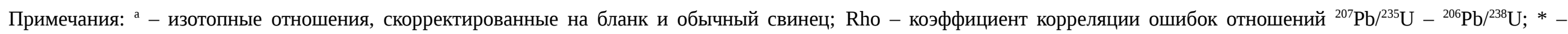
навеска циркона не определялась Величины ошибок (2б) соответствуют последним значащим цифрам. 


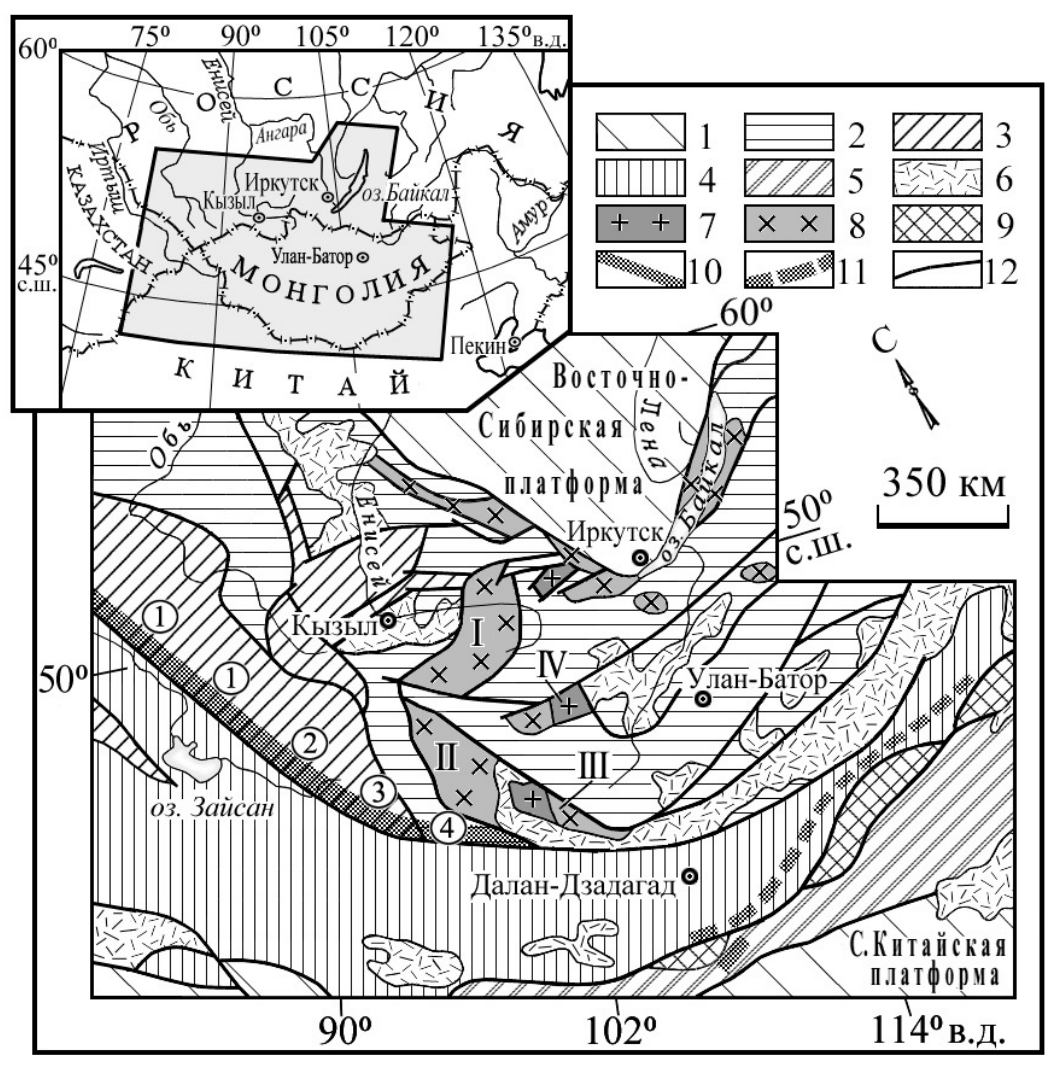




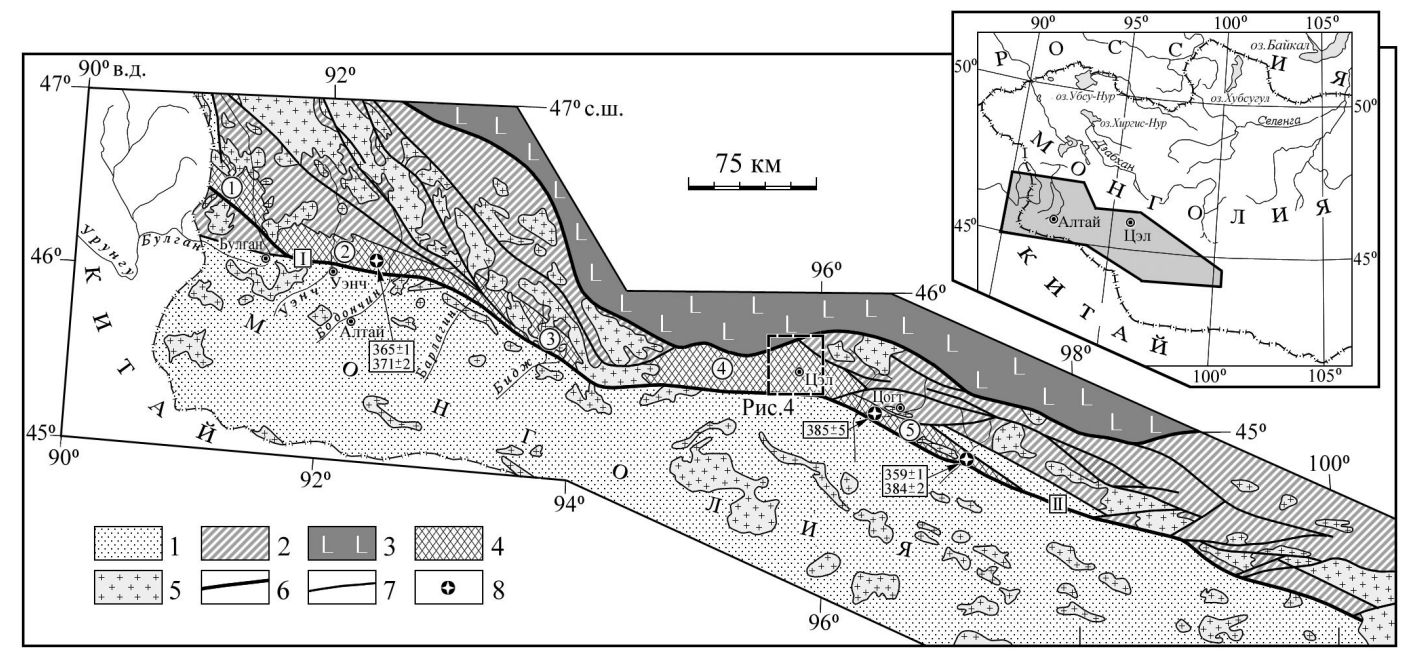




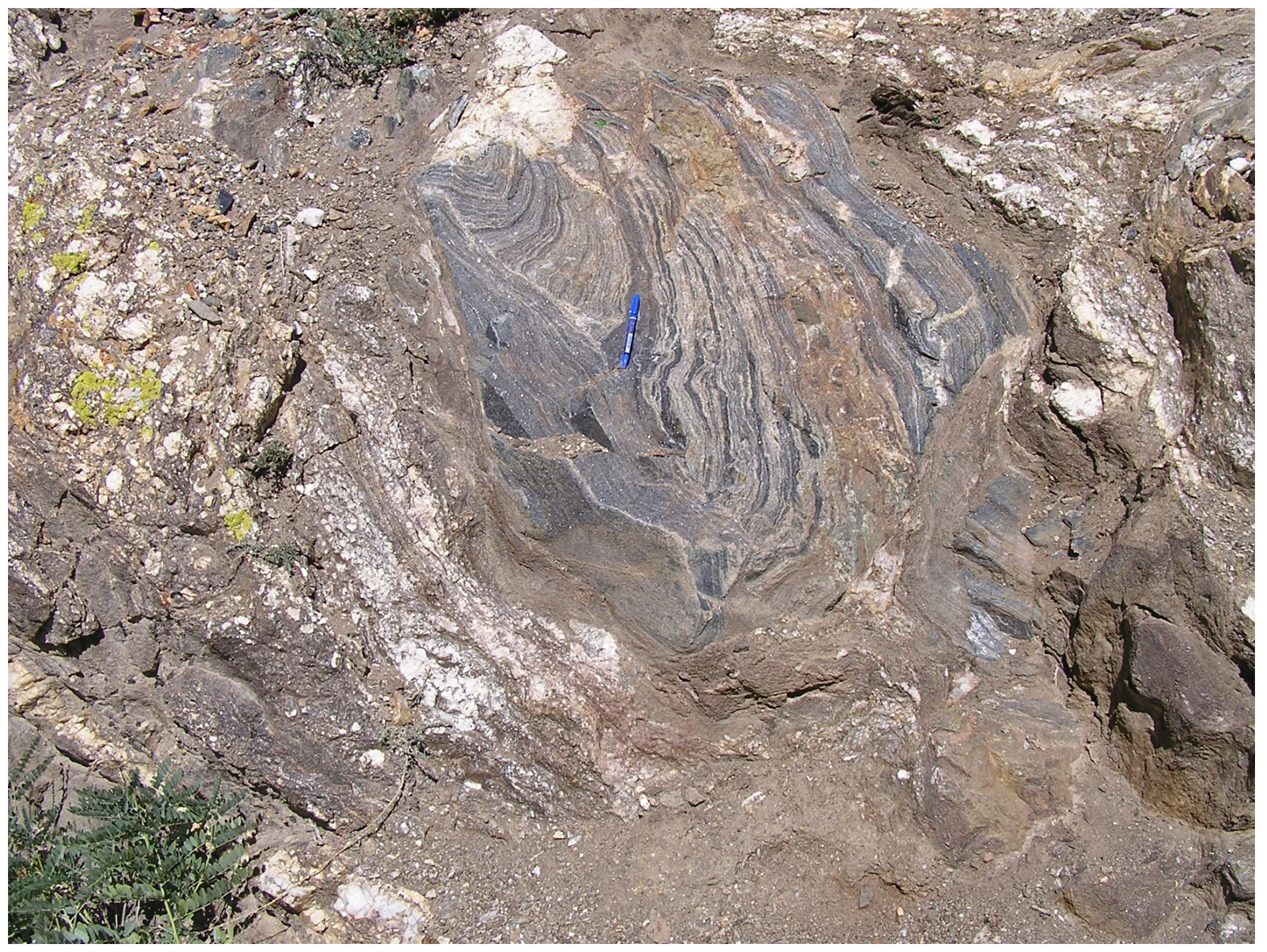




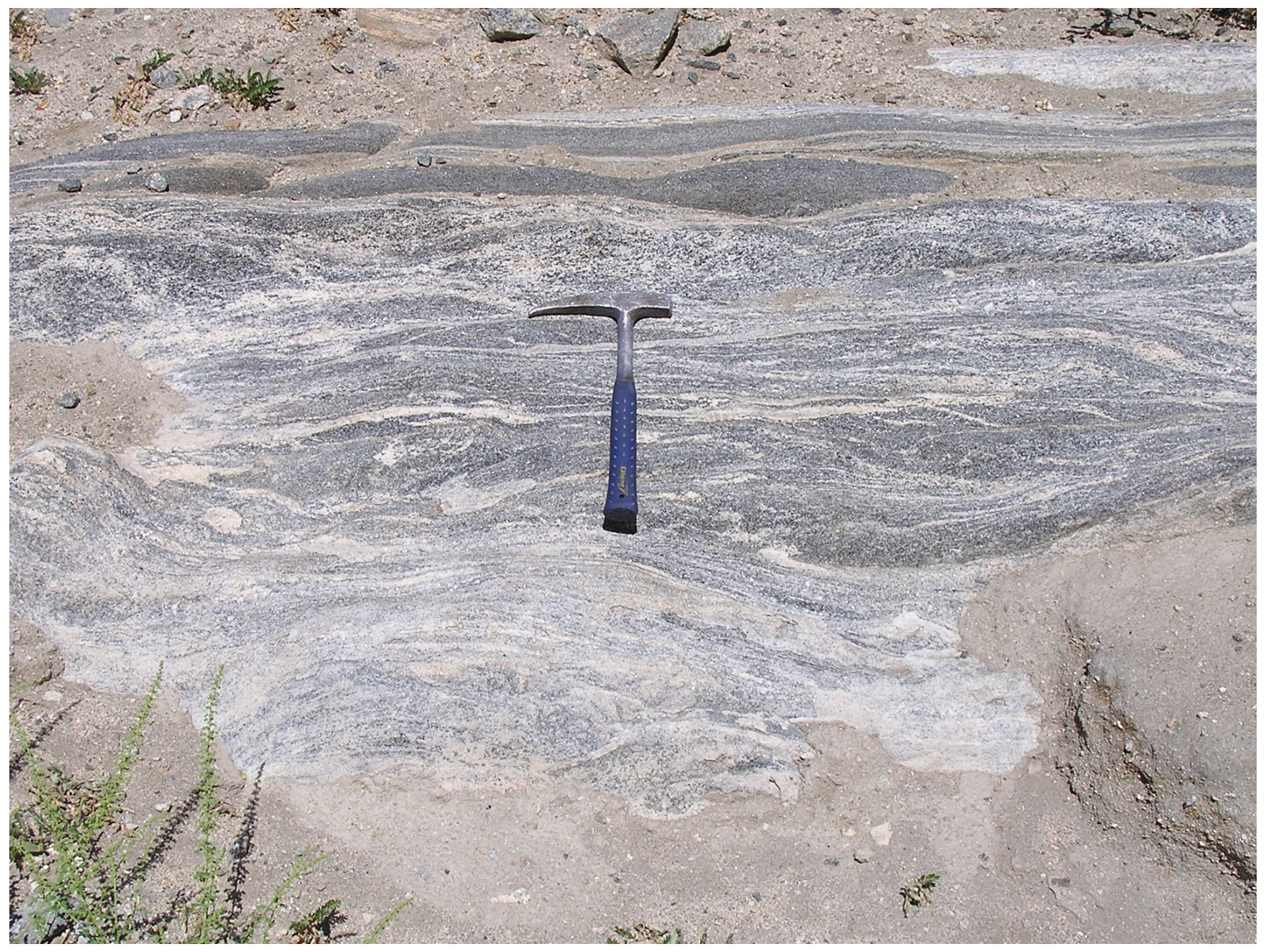









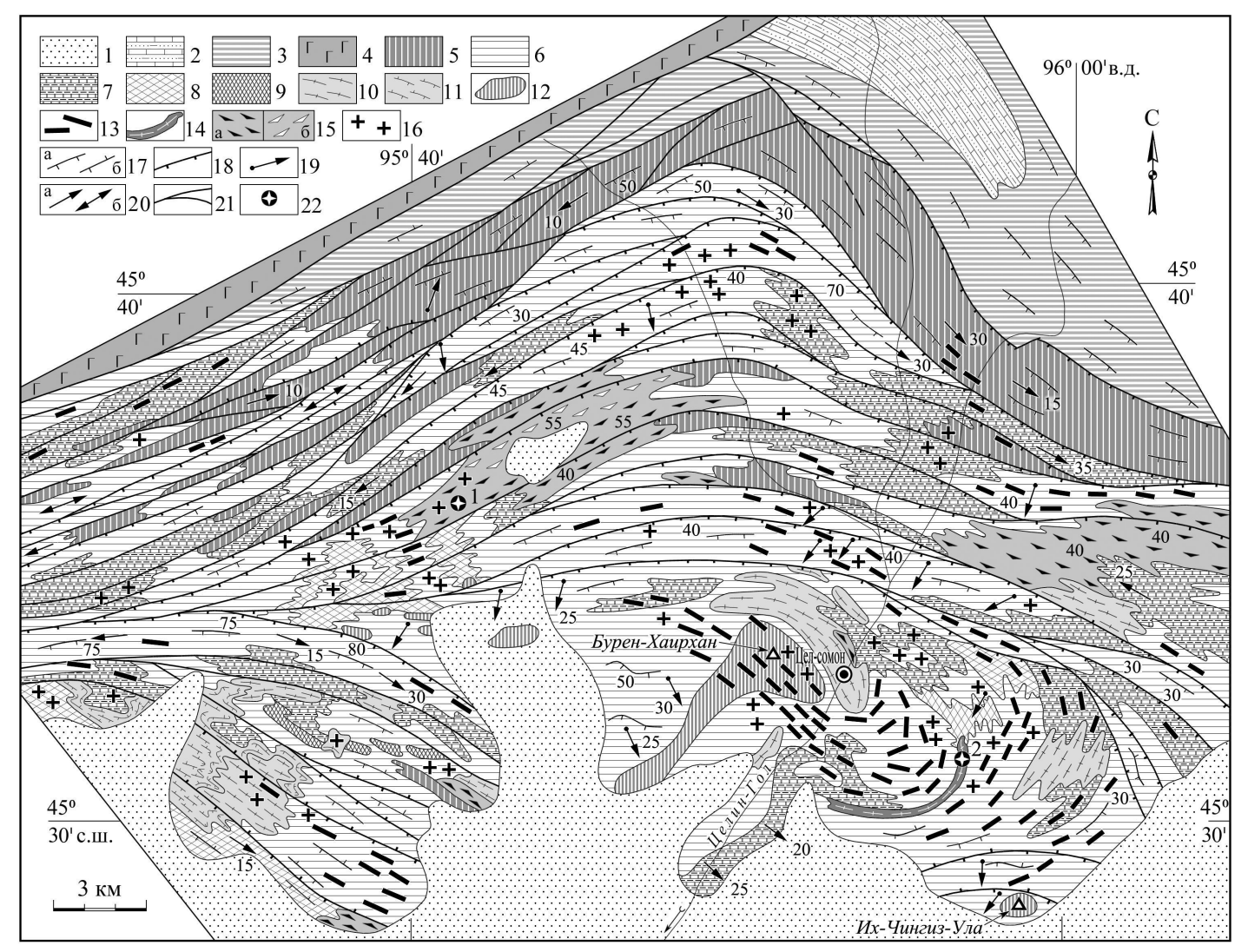




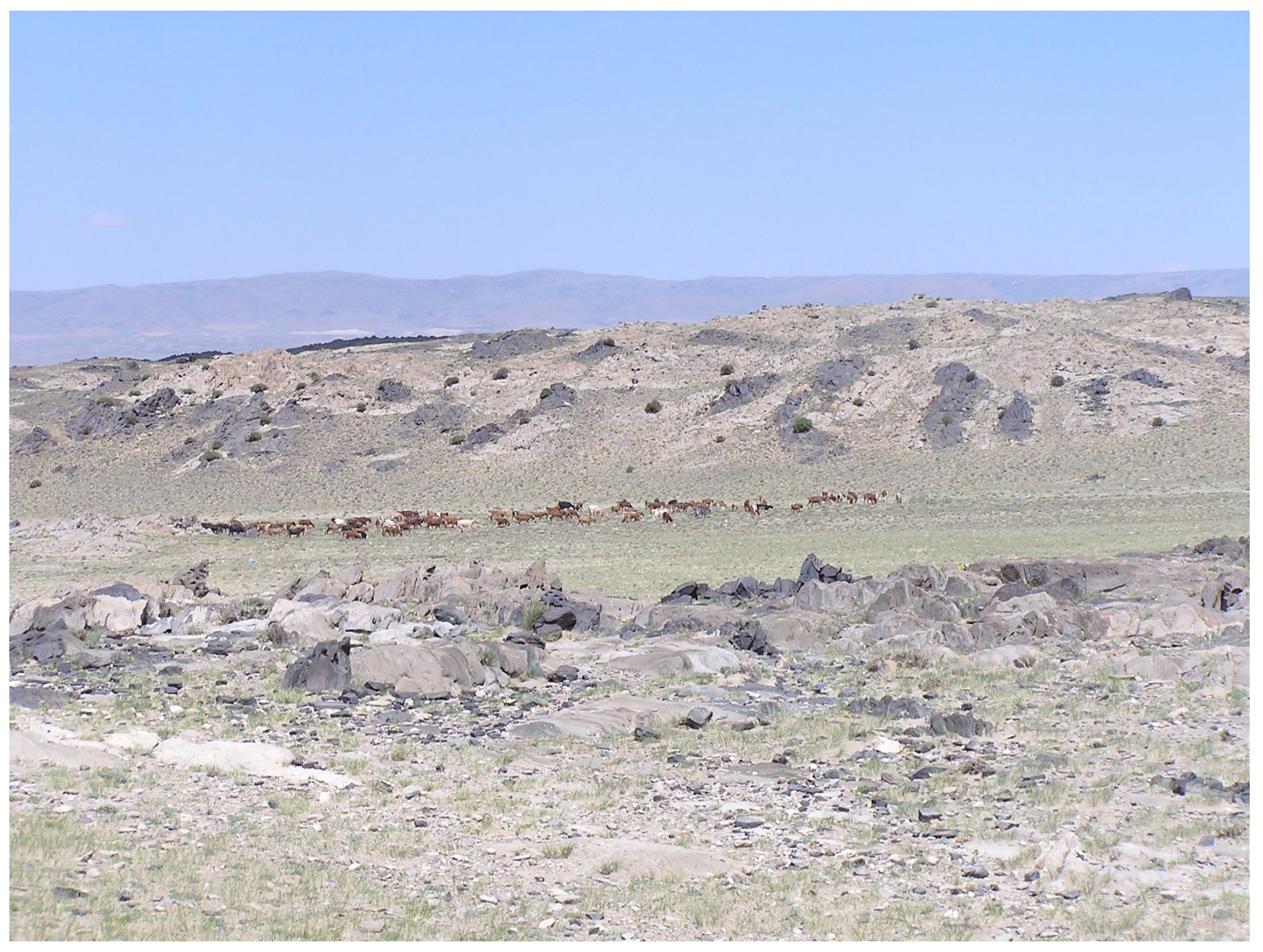




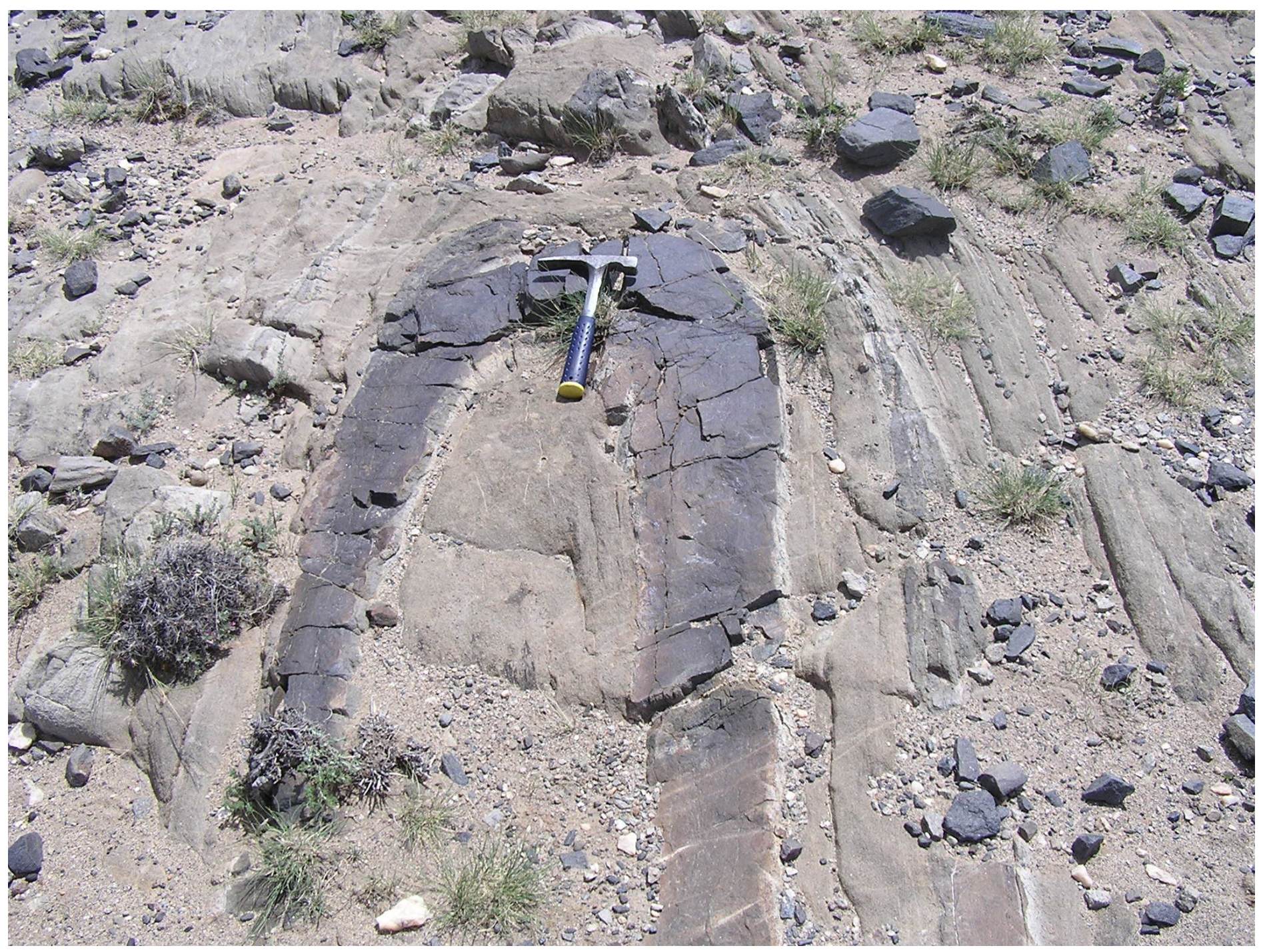




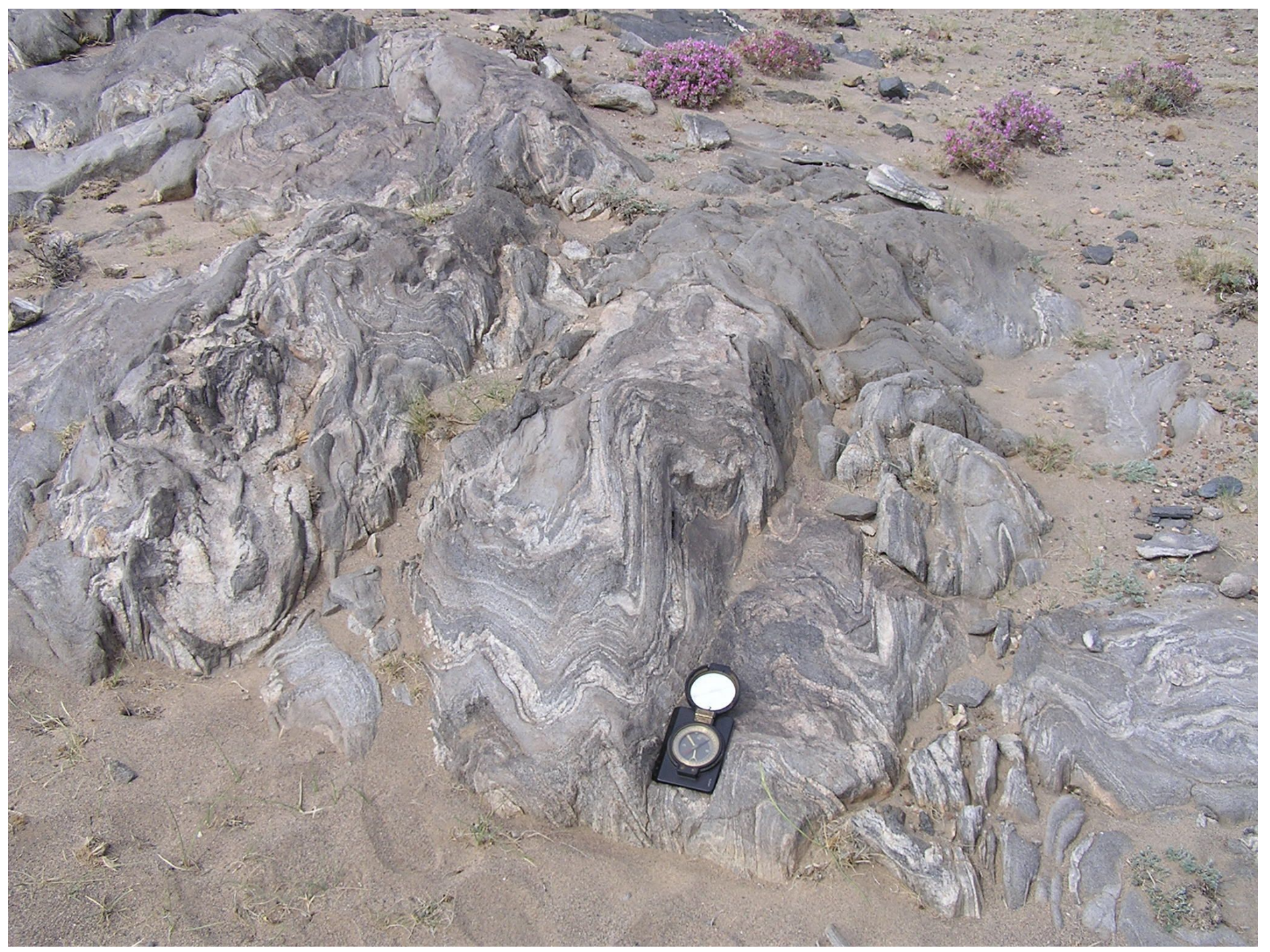




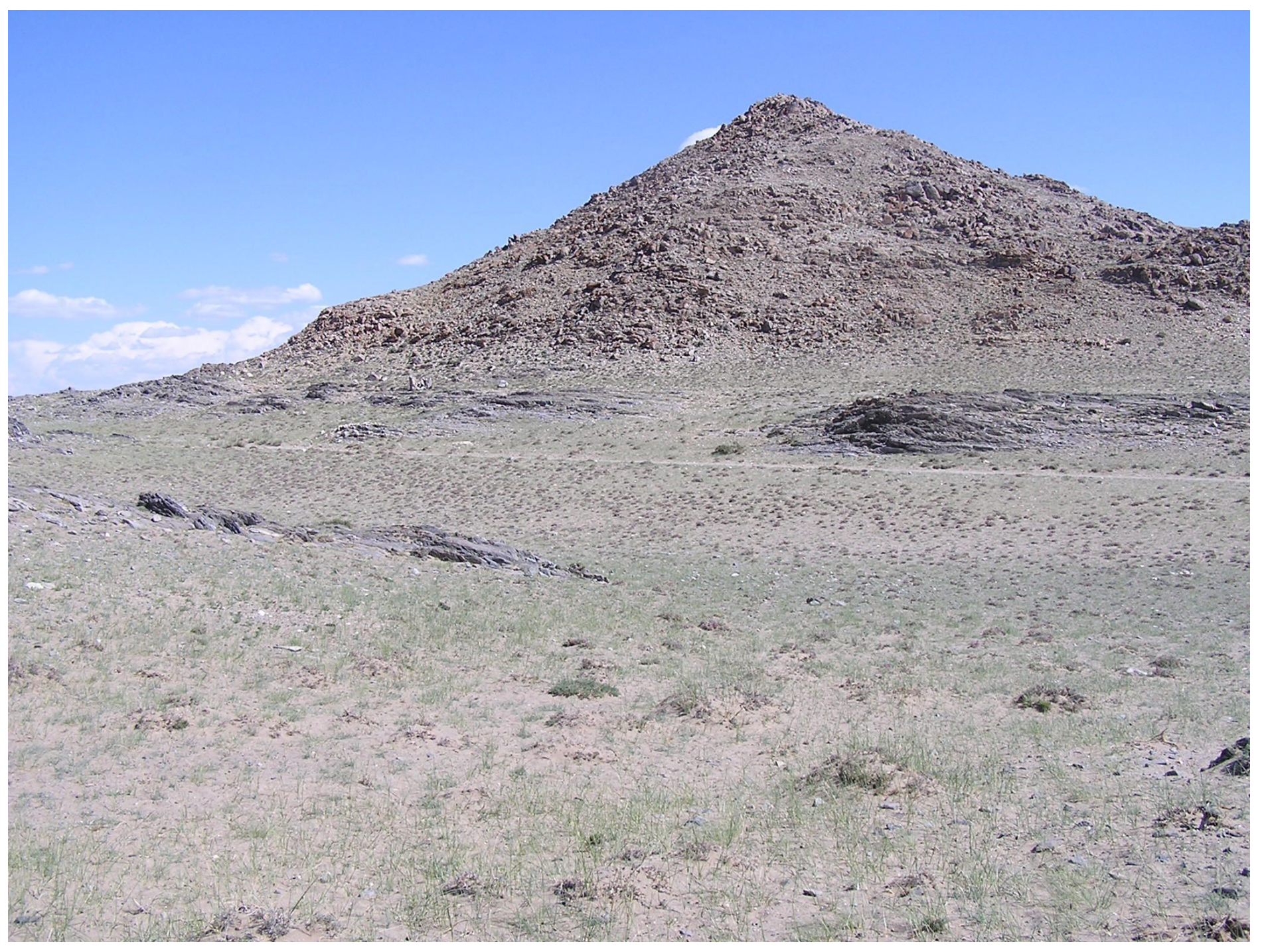




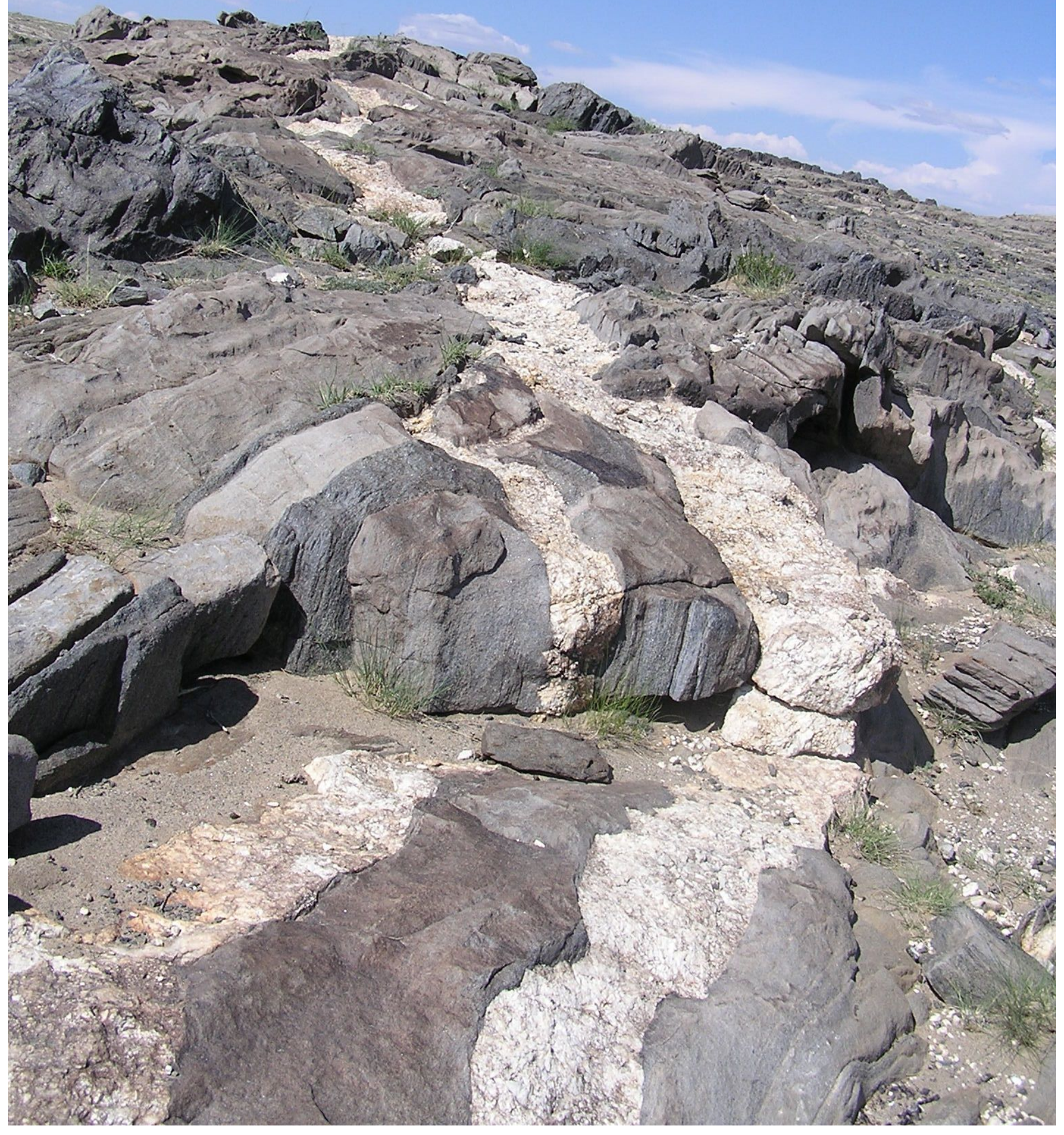



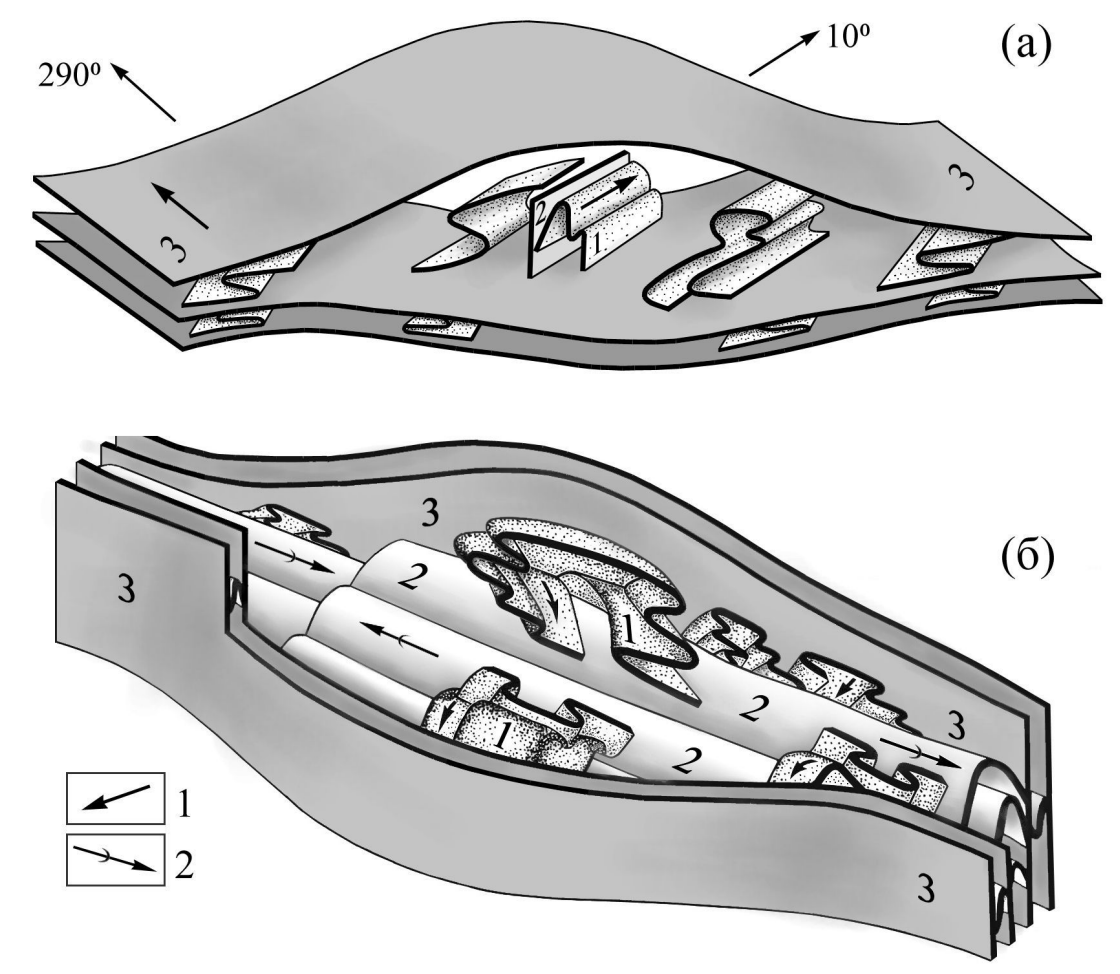


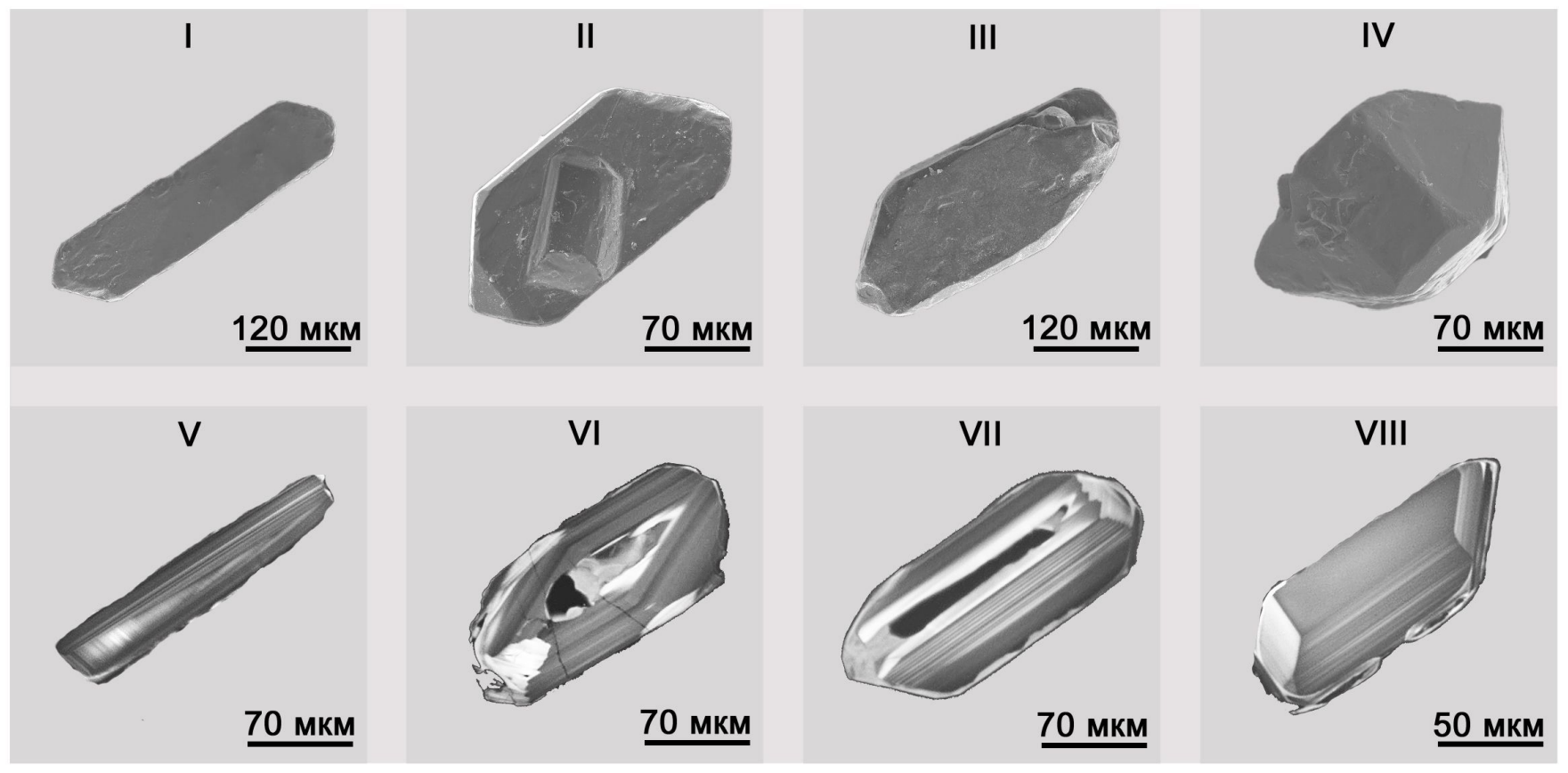




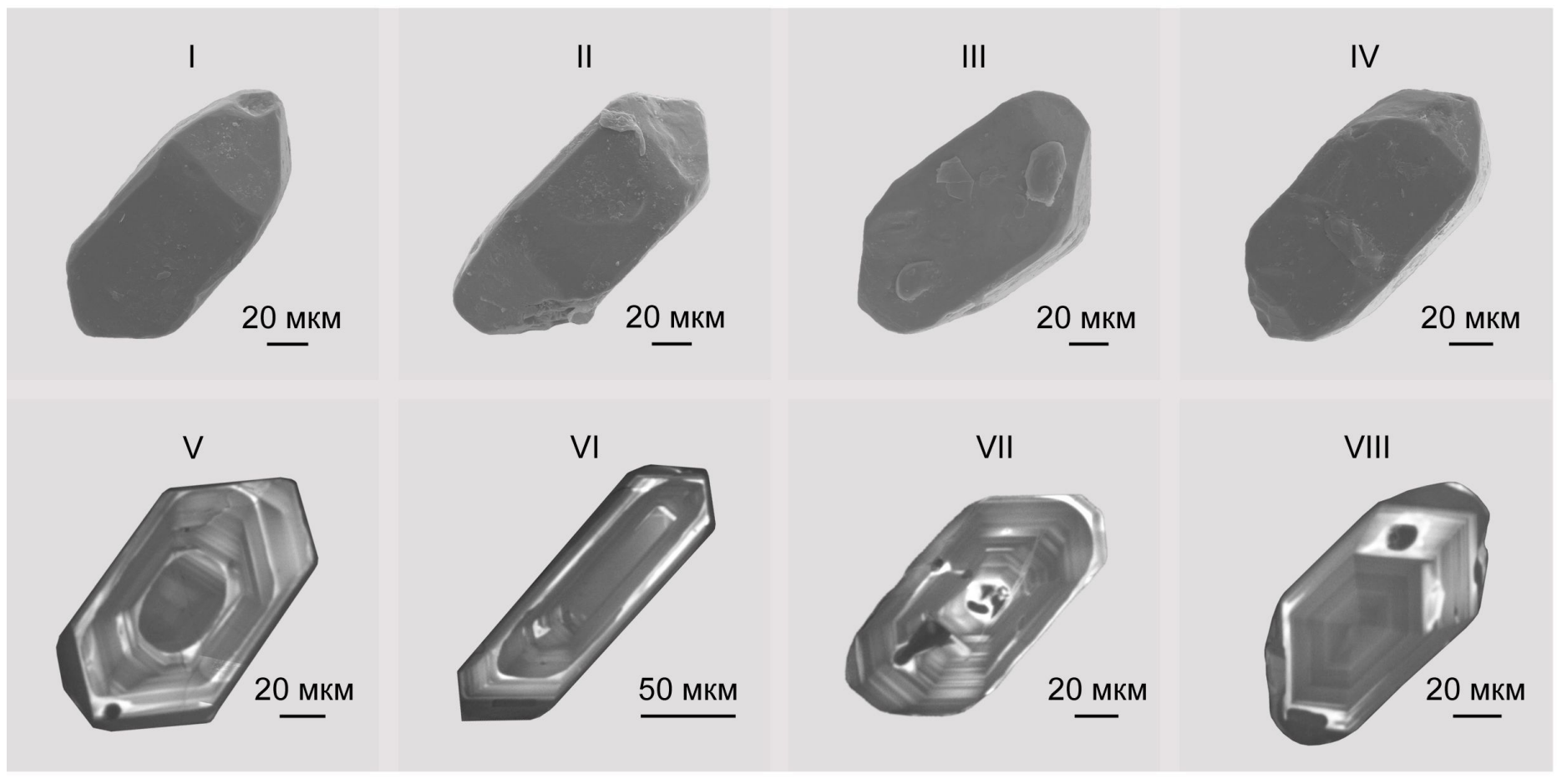



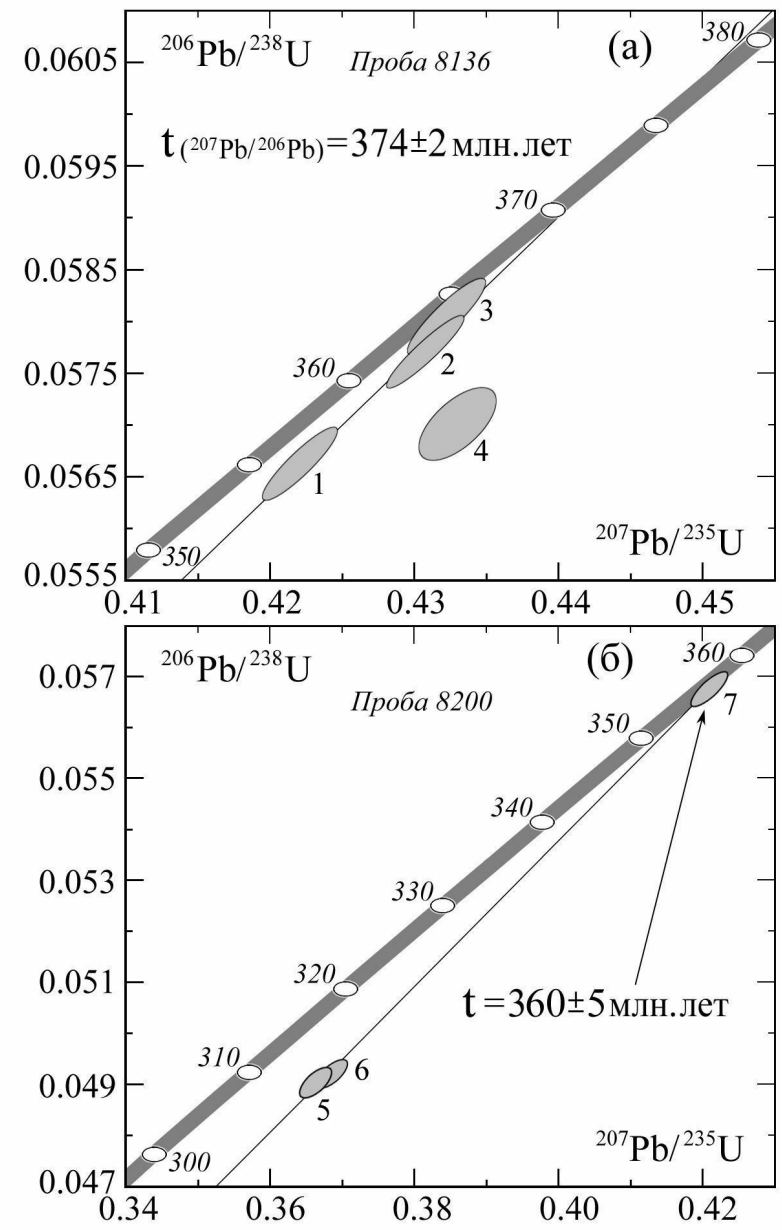


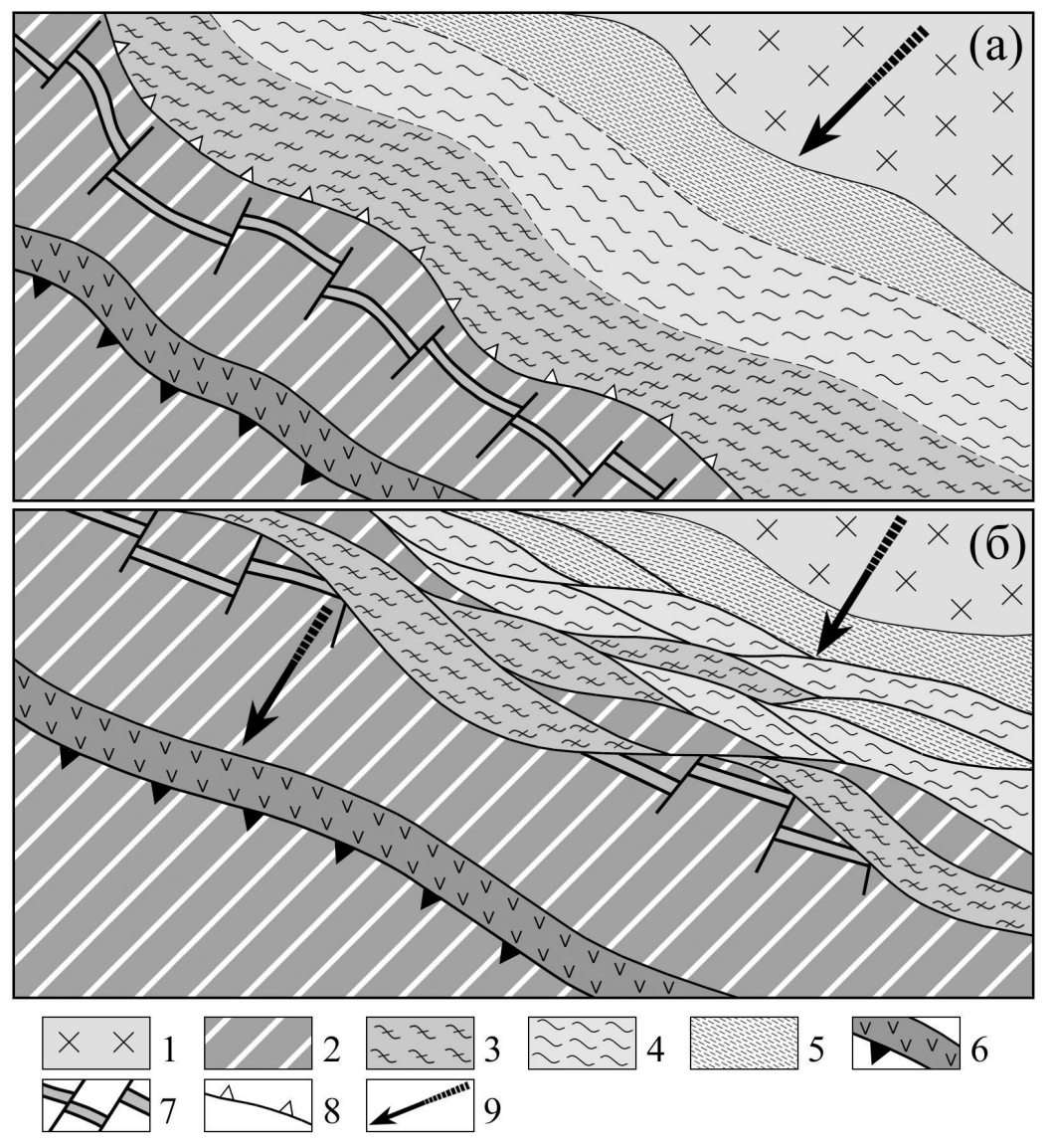

